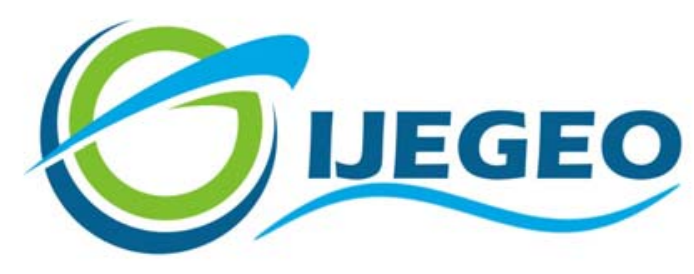

International Journal of Environment and Geoinformatics (IJEGEO) is an international, multidisciplinary, peer reviewed, open access journal.

\title{
On the Use of Mathematical Models for Wastewater Treatment: A Review and Analysis of Activated Sludge Models ASM1 and ASM3
}

\section{Başak SAVUN HEKİMOĞLU}

\author{
Chief in Editor \\ Prof. Dr. Cem Gazioğlu \\ Co-Editors \\ Prof. Dr. Dursun Zafer Şeker, Prof. Dr. Şinasi Kaya, \\ Prof. Dr. Ayşegül Tanık and Assist. Prof. Dr. Volkan Demir
}

Editorial Committee (March 2021)

\begin{abstract}
Assoc. Prof. Dr. Abdullah Aksu (TR), Assit. Prof. Dr. Uğur Algancı (TR), Prof. Dr. Bedri Alpar (TR), Assoc. Prof. Dr. Aslı Aslan (US), Prof. Dr. Levent Bat (TR), Prof. Dr. Paul Bates (UK), İrşad Bayırhan (TR), Prof. Dr. Bülent Bayram (TR), Prof. Dr. Luis M. Botana (ES), Prof. Dr. Nuray Çağlar (TR), Prof. Dr. Sukanta Dash (IN), Dr. Soofia T. Elias (UK), Prof. Dr. A. Evren Erginal (TR), Assoc. Prof. Dr. Cüneyt Erenoğlu (TR), Dr. Dieter Fritsch (DE), Prof. Dr. Çiğdem Göksel (TR), Prof.Dr. Lena Halounova (CZ), Prof. Dr. Manik Kalubarme (IN), Dr. Hakan Kaya (TR), Assist. Prof. Dr. Serkan Kükrer (TR), Assoc. Prof. Dr. Maged Marghany (MY), Prof. Dr. Michael Meadows (ZA), Prof. Dr. Nebiye Musaoğlu (TR), Prof. Dr. Masafumi Nakagawa (JP), Prof. Dr. Hasan Özdemir (TR), Prof. Dr. Chryssy Potsiou (GR), Prof. Dr. Erol Sarı (TR), Prof. Dr. Maria Paradiso (IT), Prof. Dr. Petros Patias (GR), Prof. Dr. Elif Sertel (TR), Prof. Dr. Nüket Sivri (TR), Prof. Dr. Füsun Balık Sanlı (TR), Prof. Dr. Uğur Sanlı (TR), Duygu Ülker (TR), Prof. Dr. Seyfettin Taş (TR), Assoc. Prof. Dr. Ömer Suat Taşkın (TR), Assist. Prof. Dr. Tuba Ünsal (TR), Dr. Manousos Valyrakis (UK), Dr. İnese Varna (LV), Dr. Petra Visser (NL), Prof. Dr. Selma Ünlü (TR), Assoc. Prof. Dr. Oral Yağcı (TR), Prof. Dr. Murat Yakar (TR), Assoc. Prof. Dr. İ. Noyan Yılmaz (AU); Assit. Prof. Dr. Sibel Zeki (TR)
\end{abstract}


Research Article

\title{
On the Use of Mathematical Models for Wastewater Treatment: A Review and Analysis of Activated Sludge Models ASM1 and ASM3
}

\author{
Basak Savun-Hekimoğlu \\ Istanbul University, Institute of Marine Sciences and Management, Istanbul/Turkey
}

E-mail: basak.savun@istanbul.edu.tr

Received: $\quad 14 \quad$ July 2020 Accepted: $\quad 16$ Nov 2020

How to cite: Savun-Hekimoğlu, B. (2021). On the Use of Mathematical Models for Wastewater Treatment: A Review and Analysis of Activated Sludge Models ASM1 and ASM3. International Journal of Environment and Geoinformatics (IJEGEO), 8(1):001-018. doi: 10.30897/ ijegeo.794643.

\begin{abstract}
Mathematical models describing the dynamics of key biochemical processes in conventional activated sludge processes are commonly used to design and operate wastewater treatment plants. Since the introduction of the first activated sludge model, namely Activated Sludge Model No. 1 (ASM1), in 1987 by the International Water Association, ASM models received considerable attention and several extensions were suggested. In this study, we briefly review the literature on two important activated sludge models, ASM1 and ASM3. Our literature review indicates that despite the presence of many articles on ASM there is no study on the parameter sensitivity of these differential equation models. In the second part of the study, these two models are simulated in MATLAB with different initial values and parameter combinations to develop further insight into the model structures. In the third part of the study, experiments with ASM1 and ASM3 models are conducted in MATLAB and a basic sensitivity analysis is applied for the parameters of the two models.
\end{abstract}

Keywords: Activated Sludge Models, ASM1, ASM3, Sensitivity Analysis Introduction

The activated sludge process is the most widely used technology for biological wastewater treatment since its development at the beginning of the 20th century. It is the most cost-effective, safe and flexible (can be adapted for any kind of wastewater) treatment option with highquality effluent producing capability (Mulas, 2006). A bacterial biomass suspension (the activated sludge) is responsible for removing the pollutants in the activated sludge process. Depending on the design of WWTP and the particular application, in addition to organic carbon, biological nitrogen and phosphorus removal can also be achieved. The complexity of the combined nitrogen and phosphorus removal processes make modeling activated sludge processes a standard step of WWTP design and operation. This stimulated a number of different activated sludge process configurations over time (Gernaey et al., 2004; Rieger et al., 2012; Makinia et al., 2020).

In the design phase of a WWTP, mathematical models including kinetic equations of chemical reactions, are employed to explain dynamic changes in carbon oxidation, nitrification, denitrification and other processes (Henze et al., 2000). Analysis on the behavior of the activated sludge systems provides an insight into a large number of reactions between elements. Specifically, these mathematical models explain both kinetics (rate-concentration dependence) of each process and their stoichiometry with Gujer Matrix notation (Wu et al., 2016).
In 1982, the International Association for Water Pollution Research and Control (IAWPRC) developed ASM1 to primarily explain organic compound and nitrogen removal, with the simultaneous use of oxygen and nitrate as electron acceptors. The model provides a clear explanation of sludge production and measures organic matter concentration, COD (Chemical Oxygen Demand) (Brdjanovic et al., 2015). The model is based on Monod Kinetics that predicts biological reaction processes. ASM1 has been a guide for many scientific and practical projects and implemented in the majority of commercial softwares for modeling and simulating nitrogen removal of WWTPs (Van Loosdrecht and Lopez-Vazquez, 2015). More on ASM1 implementations on different software platforms can be found in Copp (2002).

Over the years, several studies have been conducted on enhanced biological phosphorus removal and the acquired knowledge led to the publication of ASM2 in 1995. ASM2 is a more complex model as it considers the removal of phosphorus in addition to organic substances and nitrogen. In order to deal with phosphorus removal, biological (processes of phosphorus-accumulating organisms) and chemical (chemical precipitation of phosphates) processes were included in the model. However, after the publication of ASM2, it has been shown that a fraction of phosphorus-accumulating organisms (PAOs) can denitrify (Gernaey et al., 2004; Drewnowski et al., 2020). Therefore, in 1999, ASM2 
was expanded into the ASM2d which considers the denitrification caused by PAOs (Makinia et al., 2020).

As for available data, ASM2d seemed to be overparametrized, which would need a more systematic method of calculation (Brun et al . 2002). In parallel with these developments, a growing awareness of PAO's cellinternal biochemistry resulted in the development of a metabolic model called TUDP. The TUDP model defines enhanced biological phosphorus removal's anaerobic and aerobic phases based on intracellular storage compounds. As ASM2 is beyond the scope of this paper, for further details on ASM2 and its variations we cite Henze et al. (2000).

With more than 10 years of experience in applying ASM1, some of this model's defects have become evident including (Hauduc et al., 2010):

- The effects of nitrogen, phosphorus and other inorganic nutrient limitations on the removal of organic substrate and cell growth have not been considered. However, if required, it is simple to add limitation terms in the model.

- The nitrification coefficients are assumed to be constant and have some inhibitory effects on the wastewater components.

- Heterotrophic biomass is homogeneous and changes in species diversity do not occur over time. This suggests that the impacts on sludge settleability of substrate concentration gradients, reactor configuration, etc. are not considered.

- Hydrolysis of organic matter and organic nitrogen is combined and occurs at the same rate.

- The heterotrophic yield coefficient is not influenced by the form of electron acceptor.

- Instant concentration of organic particulate matter in biomass is assumed.

- ASM1 is designed for urban wastewater treatment modeling and therefore it is not recommended that the model is applied to systems where industrial inputs influence wastewater characteristics.

- ASM1 does not include processes that represent anaerobic behavior. Thus, simulations of systems with large portions of the volume of anaerobic reactor can cause errors.

- ASM1 cannot handle high levels of nitrite.

- ASM1 is not designed to handle very high load or low sludge retention time (SRT) $(<1$ day) activates sludge systems.

In 1999, ASM3 was introduced to correct these shortcomings of ASM1. ASM3 model was published to become the new standard model with the addition of new variables and coefficients to consider the storage of organic compounds. In addition, ASM3 provides a more realistic description of decay processes. Two of the ASM models, ASM1 and ASM3, consider only the removal of carbon and nitrogen, while others consider biological phosphorus reduction as well.
Although many deficiencies have been corrected and new insights into the systems have been introduced with later developed ASM models, it is important to note that ASM1 remains the most widely used ASM (Hauduc et al., 2013). An international survey also showed that ASM1 is the first preference of ASM users (Hauduc et al., 2012). The aim of the study conducted by Hauduc et al. (2009) who describe the profile of ASM users, define tools/procedures used and highlight key constraints experienced during the development and application of ASM models (Hauduc et al., 2009). The survey was completed by 96 participants and the results showed that the models are used both by academics and by private companies for optimization and design purposes. ASM1 (57\%) and ASM2d (32\%) were the most used biokinetic model, followed by ASM3 and other (non-specified) versions. The survey also showed that often models are not implemented properly due to a lack of knowledge and standardized procedures (Van Loosdrecht and Lopez-Vazquez, 2015).

Only a few studies were conducted on the analysis and comparison of ASM model performances. Choubert et al. (2009) carried out a series of simulations with ASM1 by using the default parameter values and parameter values obtained from laboratory-scale experiments. A wide range of operating conditions was investigated and the simulation results were compared with the real data from 13 full-scale WWTPs. The results of that study showed that simulations using the default set of parameters tend to over predict the rate of nitrification and under predict the denitrification whereas the modified set of parameters leads to more realistic predictions of various operating conditions. Gernaey et al. (2004) reported that ASM3 is superior to ASM1 for calibration as the growth-death concept has been replaced by the death-regeneration metabolic. The authors also found that a shift in a parameter value may affect all state variables directly in ASM1, while this effect is significantly lower in ASM3. Guisasola et al. (2005) have conducted experimental analysis and reported that ASM3 provided better predictions than ASM1. In the study of Shahriarie et al (2002), ASM3 described the system's carbon removal more clearly than other simulated models (ASM1, ASM2, and ASM2d). A brief review of the literature review reveals that parameter sensitivity analysis of ASM1 and ASM3 has not been studied rigorously. In this study, we aim to fill this research gap by using one at a time sensitivity sampling and standardized regression coefficients.

In the next section, brief descriptions of ASM1 and ASM3 models' main processes and kinetic equations, which are used in MATLAB simulations and analyses, are provided.

\section{Description of ASM1 and ASM3 Models Activated Sludge Model No. 1 (ASM1)}

In essence, ASM1 consists of four major processes (Henze et al., 1987): i) biomass production, ii) biomass decay, iii) organic nitrogen ammonification, iv) organic 
particulate matter hydrolysis. Two types of microorganisms perform the reactions in the ASM1 model: heterotrophic and autotrophic. State variables of the ASM1 model are given in Table 1. Table 2 summarizes the different mechanisms in ASM1.

Table 1. ASM1 State Variables (Henze et al., 1987).

\begin{tabular}{|c|c|}
\hline State Variable & ASM1 Notation \\
\hline Soluble inert organic matter & $\mathrm{gCOD} / \mathrm{m}^{3}$ \\
\hline Readily biodegradable substrate & $\mathrm{gCOD} / \mathrm{m}^{3}$ \\
\hline Particulate inert organic matter & $\mathrm{gCOD} / \mathrm{m}^{3}$ \\
\hline Slowly biodegradable substrate & $\mathrm{gCOD} / \mathrm{m}^{3}$ \\
\hline Active heterotrophic biomass & $\mathrm{gCOD} / \mathrm{m}^{3}$ \\
\hline Active autotrophic biomass & $\mathrm{gCOD} / \mathrm{m}^{3}$ \\
\hline Part. prod. from biomass decay & $\mathrm{gCOD} / \mathrm{m}^{3}$ \\
\hline Dissolved Oxygen & $\mathrm{gO}_{2} / \mathrm{m}^{3}$ \\
\hline Nitrite and Nitrate Nitrogen & $\mathrm{gN} / \mathrm{m}^{3}$ \\
\hline Free and Ionized Ammonia & $\mathrm{gN} / \mathrm{m}^{3}$ \\
\hline Soluble biodegr. organic N & $\mathrm{gN} / \mathrm{m}^{3}$ \\
\hline Part. biodegr. organic $\mathrm{N}$ & $\mathrm{gN} / \mathrm{m}^{3}$ \\
\hline Alkalinity & Molar units \\
\hline Table 2. ASM1 Basic Proc & s (Henze et al., 1987). \\
\hline Process & Basic Reaction \\
\hline $1 \begin{array}{l}\text { Aerobic growth of } \\
\text { heterotrophs }\end{array}$ & $\mathrm{S}_{\mathrm{S}}+\mathrm{S}_{\mathrm{O}}+\mathrm{S}_{\mathrm{NH}} \rightarrow \mathrm{X}_{\mathrm{BH}}$ \\
\hline $\begin{array}{l}\text { Anoxic growth of } \\
\text { heterotrophs }\end{array}$ & $\mathrm{S}_{\mathrm{S}}+\mathrm{S}_{\mathrm{NO}}+\mathrm{S}_{\mathrm{NH}} \rightarrow \mathrm{X}_{\mathrm{BH}}$ \\
\hline 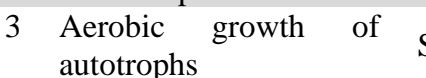 & $\mathrm{S}_{\mathrm{O}}+\mathrm{S}_{\mathrm{NH}} \rightarrow \mathrm{X}_{\mathrm{BA}}+\mathrm{S}_{\mathrm{O}}$ \\
\hline 4 Decay of heterotrophs & $\mathrm{X}_{\mathrm{BH}} \rightarrow \mathrm{X}_{\mathrm{P}}+\mathrm{X}_{\mathrm{S}}+\mathrm{X}_{\mathrm{ND}}$ \\
\hline 5 Decay of autotrophs & $\mathrm{X}_{\mathrm{BA}} \rightarrow \mathrm{X}_{\mathrm{P}}+\mathrm{X}_{\mathrm{S}}+\mathrm{X}_{\mathrm{ND}}$ \\
\hline $6 \begin{array}{l}\text { Ammonification } \\
\text { soluble organic } \mathrm{N}\end{array} \quad$ of & $\mathrm{S}_{\mathrm{ND}} \rightarrow \mathrm{S}_{\mathrm{NH}}$ \\
\hline $\begin{array}{l}7 \text { Hydrolysis of entrapped } \\
\text { organics }\end{array}$ & $\mathrm{X}_{\mathrm{S}} \rightarrow \mathrm{S}_{\mathrm{S}}$ \\
\hline $\begin{array}{l}8 \text { Hydrolysis of entrapped } \\
\text { organic } \mathrm{N}\end{array}$ & $\mathrm{X}_{\mathrm{ND}} \rightarrow \mathrm{S}_{\mathrm{ND}}$ \\
\hline
\end{tabular}

Table 3 shows the kinetics of processes and stoichiometric matrix for carbon oxidation, nitrification and denitrification (Gujer, 2008; Henze et al., 1987). It's important to note that no conversion method involves $S_{\text {I }}$ and $\mathrm{X}_{\mathrm{I}}$. Nonetheless, since they are critical for the efficiency of the operation, they must be included in the COD computation $\left(\mathrm{COD}_{\mathrm{tot}}=\mathrm{S}_{\mathrm{I}}+\mathrm{S}_{\mathrm{S}}+\mathrm{X}_{\mathrm{I}}+\mathrm{X}_{\mathrm{S}}+\mathrm{X}_{\mathrm{BH}}+\right.$ $\mathrm{X}_{\mathrm{BA}}+\mathrm{X}_{\mathrm{P}}$ ). Hauduc et al. (2010) reported that there is no term for model nutrient (ammonia) limitation in the heterotrophic growth cycle in the kinetic rate expression which could cause negative concentration values for ammonia. According to Hauduc et al. (2010), another point to note is to perform a complete nitrogen balance. Therefore, $\mathrm{S}_{\mathrm{NI}}$ (soluble non-biodegradable organic nitrogen) and $\mathrm{X}_{\mathrm{NI}}$ (particulate non-biodegradable organic nitrogen) should be added to total soluble nitrogen in the effluent, and to total nitrogen in activated sludge, respectively.

\section{Activated Sludge Model No. 3 (ASM3)}

In the ASM3 there are 5 main processes considered: i) growth of biomass, ii) endogenous respiration, iii) storage of readily biodegradable organic substrates, iv) respiration of stored material v) hydrolysis. All 12 processes are given in Table 4 and the components of the ASM3 model are:

- $\mathrm{S}_{\mathrm{ALK}}$ : Alkalinity of the wastewater

- $\mathrm{S}_{\mathrm{I}}$ : Inert soluble organic material

- $\mathrm{S}_{\mathrm{N} 2}$ : Dinitrogen, $\mathrm{N}_{2}$

- $\mathrm{S}_{\mathrm{NH} 4}$ :Ammonium plus ammonia nitrogen

- $S_{\mathrm{NOX}}$ : Nitrate plus Nitrite Nitrogen

- $\mathrm{S}_{\mathrm{O} 2}$ : Dissolved Oxygen

- $\mathrm{S}_{\mathrm{S}}$ : Readily biodegradable substrate

- $\mathrm{X}_{\mathrm{H}}$ : Heterotrophic organisms

- $\mathrm{X}_{\mathrm{I}}$ : Inert particulate organic material

- $\mathrm{X}_{\mathrm{S}}$ : Slowly biodegradable substrates

- $\mathrm{X}_{\mathrm{STO}}$ : A cell internal storage product of heterotrophic organisms

- $\mathrm{X}_{\mathrm{A}}$ : Nitrifying organisms

- $\mathrm{X}_{\mathrm{SS}}$ : Suspended Solids

The model is presented in matrix form in Table 6. As previously mentioned, the main distinction between the ASM1 and the ASM3 versions is that the latter considers the importance of storage polymers in heterotrophic processing of activated sludge. Biomass was assumed to be produced entirely by the external substrate present in ASM1 and oxygen consumption was clarified by biomass decay after external substrate depletion. The major novelty of ASM3 is that all readily biodegradable organic substrates (Ss) under festive conditions are transformed directly into stored material $\left(\mathrm{X}_{\mathrm{STO}}\right)$. These stored compounds become the source of carbon and energy in the following famine period for growth. Fig. 1 shows the difference between ASM1 and ASM3 in COD flows.

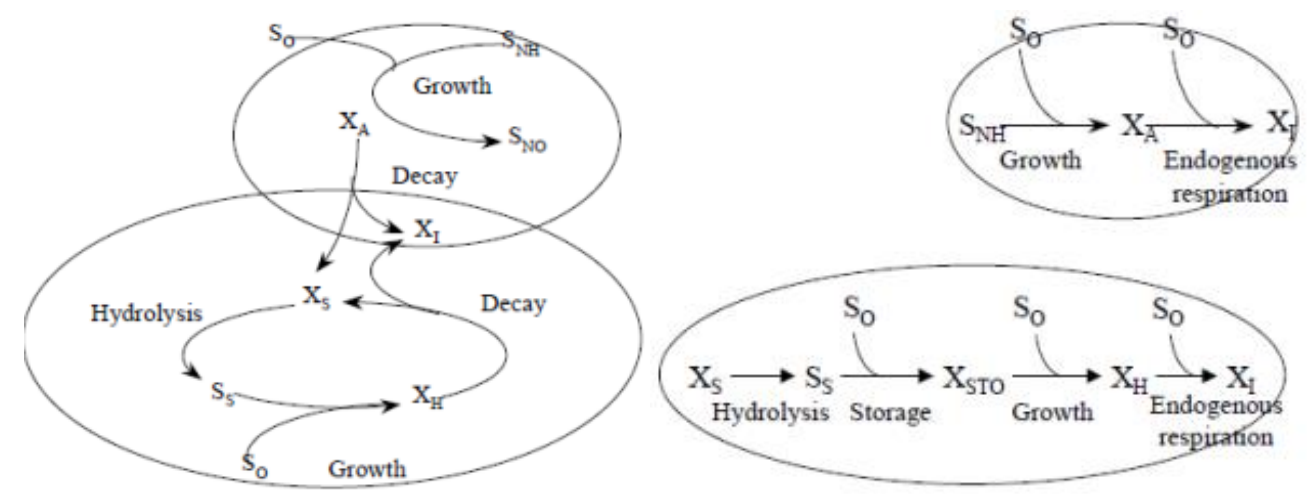

Figure 1. Flow of COD in ASM1 (a) and ASM3 (b) (Mussati et al., 2002). 
The first point to note is that the conversion processes of all groups of organisms (autotrophs and heterotrophs) are specifically separated in ASM3 while autotrophic and heterotrophic decay regeneration cycles are strongly interrelated in ASM1. This improvement in the concept of decay and the addition of the storage stage means that there are more entry points for the use of oxygen which in some cases contribute to better separation and process characterization. Second, the importance of the oxygen consumption rates of ASM3 is less significant in hydrolysis as only hydrolysis of XS in the influent is considered (Petersen et al. 2002).

Table 4. Processes in the ASM3 Model.

\begin{tabular}{ll}
1 & Hydrolysis \\
2 & Aerobic storage of $\mathrm{X}_{\mathrm{STO}}$ \\
3 & Anoxic storage of $\mathrm{X}_{\mathrm{STO}}$ \\
4 & Aerobic growth of $\mathrm{X}_{\mathrm{H}}$ \\
5 & Anoxic growth of $\mathrm{X}_{\mathrm{H}}$ (denitrification) \\
6 & Aerobic endogenous respiration of $\mathrm{X}_{\mathrm{H}}$ \\
7 & Anoxic endogenous respiration of $\mathrm{X}_{\mathrm{H}}$ \\
8 & Aerobic respiration of $\mathrm{X}_{\mathrm{STO}}$ \\
\hline 9 & Anoxic respiraton of $\mathrm{X}_{\mathrm{STO}}$ \\
10 & Growth of $\mathrm{X}_{\mathrm{A}}$ (Nitrification) \\
11 & Aerobic endogenous respiration of $\mathrm{X}_{\mathrm{A}}$ \\
12 & Anoxic endogenous respiration of $\mathrm{X}_{\mathrm{A}}$ \\
\hline
\end{tabular}

The number of limitations mentioned above for ASM1 (see page 2), without the restriction on whether a form of electron accepter does not affect the decomposition of biomass, also applies to ASM3. Hauduc et al. (2010) states that the absent $i_{S S, S T O}$ coefficient in the parameter list is another limitation of the model. Within the initial ASM3, the biological P-removal, chemical accumulation, growth, or $\mathrm{pH}$ measurements were not included. The processes involved in the ASM3 model are given in Table 5 and the model in the matrix format is presented in Table 6 .

\section{Comparative Simulations of ASM1 and ASM3}

Mathematically, ASM1 and ASM3 models are high order differential equation systems consisting of variables in the activated sludge process. In order to analyze the behaviors of these models, they are simulated in MATLAB using ode45 solver.

Ode45 is a built-in numerical solution function that is tailored for ordinary differential equations in MATLAB. In this study, differential equation systems are coded in MATLAB scripts and called with ode45 function with specified initial values of variables and simulation horizon. These initial values are important as they indicate different operating conditions of WWTPs. Ode45 function of MATLAB numerically simulates the model for each time step within the simulation horizon. The details of these numerical experiments of the two models are described in respective subsections.

\section{Simulation of ASM1 Model}

Mathematically, the ASM1 model is a 13th order differential equation system. To solve this model numerically, rate equations given in the right column of Table 3 and their coefficients are entered into MATLAB. Typical parameter values are given in Table 7. These parameter values are taken from Henze et al. (1987). The short definition of model compounds and typical wastewater composition (primary effluent) are given in Table 8 .

Table 7. Typical parameter values at neutral $\mathrm{pH}$ (Henze et al., 1987).

\begin{tabular}{|c|c|c|}
\hline $\begin{array}{l}\text { Symbol } \\
\text { Stoichio }\end{array}$ & \multicolumn{2}{|c|}{ Stoichiometric parameters } \\
\hline $\mathrm{Y}_{\mathrm{A}}$ & $\begin{array}{l}\mathrm{g} \text { cell COD formed }(\mathrm{g} \mathrm{N} \\
\text { oxidized }^{-1}\end{array}$ & 0.24 \\
\hline $\mathrm{Y}_{\mathrm{H}}$ & $\begin{array}{l}\mathrm{g} \text { cell COD formed (g COD } \\
\text { oxidized) }^{-1}\end{array}$ & 0.67 \\
\hline$f_{p}$ & dimensionless & 0.08 \\
\hline $\mathrm{i}_{\mathrm{XB}}$ & $\mathrm{g} \mathrm{N}(\mathrm{gCOD})^{-1}$ in biomass & 0.086 \\
\hline $\mathrm{i}_{\mathrm{XE}}$ & $\begin{array}{l}\mathrm{g} \mathrm{N}(\mathrm{gCOD})^{-1} \text { in endogenous } \\
\text { mass }\end{array}$ & 0.06 \\
\hline \multicolumn{3}{|c|}{ Kinetic parameters } \\
\hline$\mu_{\mathrm{H}, \max }$ & day $^{-1}$ & 6 \\
\hline $\mathrm{K}_{\mathrm{S}}$ & $\mathrm{g} \mathrm{COD} \mathrm{m}^{-3}$ & 20 \\
\hline $\mathrm{K}_{\mathrm{OH}}$ & $\mathrm{g} \mathrm{O}_{2} \mathrm{~m}^{-3}$ & 0.20 \\
\hline $\mathrm{K}_{\mathrm{NO}}$ & $\mathrm{g} \mathrm{NO}_{3}-\mathrm{N} \mathrm{m}^{-3}$ & 0.50 \\
\hline$b_{\mathrm{H}}$ & day $^{-1}$ & 0.62 \\
\hline$\eta_{g}$ & dimensionless & 0.8 \\
\hline$\eta_{\mathrm{h}}$ & dimensionless & 0.4 \\
\hline $\mathrm{k}_{\mathrm{h}}$ & $\begin{array}{l}\text { g slowly biodegradable COD } \\
\text { (gcell COD.day) }^{-1}\end{array}$ & 3 \\
\hline $\mathrm{K}_{\mathrm{x}}$ & 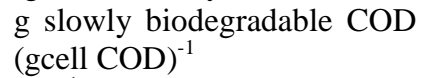 & 0.03 \\
\hline$\mu_{\mathrm{A}, \max }$ & day $^{-1}$ & 0.80 \\
\hline $\mathrm{K}_{\mathrm{NH}}$ & $\mathrm{g} \mathrm{NH}_{3}-\mathrm{N} \mathrm{m}^{-3}$ & 1 \\
\hline $\mathrm{K}_{\mathrm{OA}}$ & $\mathrm{g} \mathrm{O}_{2} \mathrm{~m}^{-3}$ & 0.4 \\
\hline $\mathrm{k}_{\mathrm{a}}$ & $\mathrm{m}^{3} \mathrm{COD}$ (g. day) $)^{-1}$ & 0.08 \\
\hline
\end{tabular}

Table 8. Short definition of model compounds and typical wastewater composition (Henze et al., 1987).

\begin{tabular}{|c|c|c|}
\hline $\begin{array}{l}\text { Compounds } \\
\text { Dissolved compounds }\end{array}$ & $\begin{array}{l}\text { Concent } \\
\text { ration }\end{array}$ & Units \\
\hline $\mathrm{S}_{\mathrm{O} 2}$ (dissolved oxygen) & 0 & $\mathrm{gO}_{2} \mathrm{~m}^{-3}$ \\
\hline $\mathrm{S}_{\mathrm{I}}$ (soluble inert organics) & 30 & $\mathrm{gCOD} \mathrm{m}^{-3}$ \\
\hline $\begin{array}{l}\mathrm{S}_{\mathrm{S}} \quad \text { (Readily biodegradable } \\
\text { substrates) }\end{array}$ & 60 & $\mathrm{gCOD} \mathrm{m}^{-3}$ \\
\hline $\mathrm{S}_{\mathrm{NH} 4}($ Ammonium $)$ & 16 & $\mathrm{gN} \mathrm{m}^{-3}$ \\
\hline $\begin{array}{l}\mathrm{S}_{\mathrm{N} 2} \text { (dinitrogen released by } \\
\text { denitrification) }\end{array}$ & 0 & $\mathrm{gN} \mathrm{m}^{-3}$ \\
\hline $\mathrm{S}_{\mathrm{NOX}}($ ntrite plus nitrate $)$ & 0 & $\mathrm{gN} \mathrm{m}^{-3}$ \\
\hline $\mathrm{S}_{\mathrm{ALK}}$ (alkalinity, bicarbonate) & 5 & $\begin{array}{l}\text { mole } \\
\mathrm{HCO}_{3} \mathrm{~m}^{-3}\end{array}$ \\
\hline $\begin{array}{l}\text { Particulate compounds } \\
X_{I} \text { (inert particulate organics) }\end{array}$ & 25 & $\mathrm{gCOD} \mathrm{m}^{-3}$ \\
\hline $\begin{array}{l}\text { Xs (slowly biodegradable } \\
\text { substrates) }\end{array}$ & 115 & $\mathrm{gCOD} \mathrm{m}^{-3}$ \\
\hline $\mathrm{X}_{\mathrm{H}}$ (Heterotrophic biomass) & 30 & $\mathrm{gCOD} \mathrm{m}^{-3}$ \\
\hline $\begin{array}{l}\mathrm{X}_{\text {STO (Organics }} \text { stored by } \\
\text { heterotrophs) }\end{array}$ & 0 & $\mathrm{gCOD} \mathrm{m}^{-3}$ \\
\hline $\begin{array}{l}\mathrm{X}_{\mathrm{A}} \text { (autotrophic, nitrifying } \\
\text { biomass) }\end{array}$ & $>0$ & $\mathrm{gCOD} \mathrm{m}^{-3}$ \\
\hline $\mathrm{X}_{\mathrm{SS}}$ (total suspended solids) & 125 & $\mathrm{gSS} \mathrm{m}^{-3}$ \\
\hline
\end{tabular}


Table 3. ASM1 Matrix Format (Adapted from Henze et al., 1987).

\begin{tabular}{|c|c|c|c|c|c|c|c|c|c|c|c|c|c|}
\hline Component & $\mathbf{S}_{\mathbf{S}}$ & $\mathbf{X}_{\mathbf{I}}$ & $\mathbf{X}_{\mathbf{S}}$ & $\mathbf{X}_{\mathbf{B H}}$ & $\mathbf{X}_{\mathbf{B A}}$ & $\mathbf{X}_{\mathbf{P}}$ & $\mathbf{S}_{\mathbf{O}}$ & $\mathbf{S}_{\mathrm{NO}}$ & $\mathbf{S}_{\mathrm{NH}}$ & $\mathbf{S}_{\mathrm{ND}}$ & $\mathbf{X}_{\mathrm{ND}}$ & $\mathbf{S}_{\mathrm{ALK}}$ & $\begin{array}{l}\text { Process Rate, } \rho_{j} \\
{\left[\mathrm{ML}^{-3} \mathbf{T}^{-1}\right]}\end{array}$ \\
\hline $\begin{array}{l}\text { Process } \\
\text { (Listed in } \\
\text { Table 2) }\end{array}$ & & & & & & & & & & & & & \\
\hline 1 & $-\frac{1}{Y_{H}}$ & & & 1 & & & $-\frac{1-Y_{H}}{Y_{H}}$ & & $-i_{X B}$ & & & $-\frac{i_{X B}}{14}$ & $\mu_{H}\left(\frac{S_{S}}{K_{S}+S_{S}}\right)\left(\frac{S_{O}}{K_{o, H}+S_{O}}\right) X_{B, H}$ \\
\hline 2 & $-\frac{1}{Y_{H}}$ & & & 1 & & & & $-\frac{1-Y_{H}}{2.86 Y_{H}}$ & $-i_{X B}$ & & & $\begin{array}{l}-\frac{1-Y_{H}}{14.2 .86 Y_{H}} \\
-\frac{i_{X B}}{14}\end{array}$ & $\mu_{H}\left(\frac{S_{S}}{K_{S}+S_{S}}\right)\left(\frac{K_{O, H}}{K_{o, H}+S_{O}}\right)\left(\frac{S_{N O}}{K_{N O}+S_{N O}}\right) \eta_{B} X_{B, H}$ \\
\hline 3 & & & & & 1 & & $-\frac{4.57-Y_{A}}{Y_{A}}$ & $\frac{1}{Y_{A}}$ & $\begin{array}{l}-i_{X B} \\
-\frac{1}{Y_{A}} \\
\end{array}$ & & & $-\frac{i_{X B}}{14}-\frac{1}{7 Y_{A}}$ & $\mu_{A}\left(\frac{S_{N H}}{K_{N H}+S_{N H}}\right)\left(\frac{S_{O}}{K_{o, A}+S_{O}}\right) X_{B, A}$ \\
\hline 4 & & & $1-f_{p}$ & -1 & & $f_{p}$ & & & & & $\begin{array}{l}i_{X B} \\
-f_{p} i_{X P}\end{array}$ & & $b_{H} X_{B H}$ \\
\hline 5 & & & $1-f_{p}$ & & -1 & $f_{p}$ & & & & & $\begin{array}{l}i_{X B} \\
-f_{p} i_{X P}\end{array}$ & & $b_{A} X_{B A}$ \\
\hline 6 & & & & & & & & & 1 & -1 & & $1 / 14$ & $k_{S} S_{N D} X_{B H}$ \\
\hline 7 & 1 & & -1 & & & & & & & & & & $k_{b}\left(\frac{\frac{X_{B}}{X_{B H}}}{K_{X}+\left(X_{S} / X_{B H}\right)}\right)\left[\left(\frac{S_{O}}{K_{O, H}+S_{O}}\right)\left(\frac{K_{O, H}}{K_{o, H}+S_{O}}\right)\left(\frac{S_{N O}}{K_{N O}+S_{N O}}\right) \eta_{b}\right.$ \\
\hline 8 & & & & & & & & & & 1 & -1 & & $\rho 7\left(X_{N D} / X_{B}\right)$ \\
\hline
\end{tabular}


Table 6. ASM3 Matrix Format (Adapted from Henze et al., 2000)

\begin{tabular}{|c|c|c|c|c|c|c|c|c|c|c|c|c|c|c|}
\hline & $S_{O}$ & $S_{S}$ & $S_{N H 4}$ & $S_{\text {NOX }}$ & $S_{N 2}$ & $S_{A L K}$ & $S_{1}$ & $X_{I}$ & $X_{S}$ & $X_{H}$ & $X_{\text {STO }}$ & $X_{A}$ & $X_{S S}$ & Process rate \\
\hline 1 & & $\begin{array}{l}1 \\
-f_{S I}\end{array}$ & $\begin{array}{l}\left(1-f_{S I}\right) \\
* i_{N, S S} \\
-f_{S I *} i_{N, S I} \\
+i_{N, X S}\end{array}$ & & & $v_{1 \_S N H 4} * i_{\text {charge_SNHX }}$ & $f_{S I}$ & & -1 & & & & $-i_{S S, X S}$ & $k_{H}\left(\frac{X_{S}}{X_{H}}\right)\left(K_{X}+\frac{X_{S}}{X_{H}}\right) * X_{H}$ \\
\hline 2 & $\begin{array}{l}-(1- \\
\left.Y_{S T O, O 2}\right)\end{array}$ & -1 & $i_{N, S S}$ & & & $v_{2 \_S N H 4} * i_{\text {charge_SNHX }}$ & & & & & $Y_{S T O, 02}$ & & $\begin{array}{l}Y_{\text {STO,O2 }} \\
* i_{S S, S T O}\end{array}$ & $k_{S T O}\left[\left(\frac{S_{O}}{K_{O 2}+S_{O 2}}\right)\right]\left(\frac{S_{S}}{K_{S}+S_{S}}\right) * X_{H}$ \\
\hline 3 & & -1 & $\overline{i_{N, S S}}$ & $\begin{array}{l}-(1- \\
\left.Y_{S T O, N O X}\right) / \\
i_{N O X, N 2}\end{array}$ & $\begin{array}{l}-(1- \\
\left.Y_{S T O, N O x}\right) / \\
i_{N O X, N 2}\end{array}$ & $\begin{array}{l}v_{3 \_S N H 4} \\
* i_{\text {charge }} \text { SNH }+v_{3}{ }_{3 N O X} i_{\text {charge_SNOX }}\end{array}$ & & & & & $Y_{\text {STO,NOX }}$ & & $\begin{array}{l}Y_{S T O, N O X} \\
* i_{S S, S T O}\end{array}$ & $\begin{array}{c}k_{S T O} * \operatorname{\eta ox}\left[\left(\frac{K_{O 2}}{K_{O 2}+S_{O 2}}\right)\right] \\
{\left[\left(\frac{S_{N O x}}{K_{N O X}+S_{N O X}}\right) *\left(\frac{S_{S}}{K_{S}+S_{S}}\right)\right]} \\
* X_{H}\end{array}$ \\
\hline 4 & $\begin{array}{l}-(1- \\
\left.Y_{H, O 2}\right) / \\
Y_{H, O 2}\end{array}$ & & $i_{N, B M}$ & & & $v_{4 \_S N H 4} * i_{\text {charges }}{ }_{S N H x}$ & & & & 1 & $\begin{array}{r}-1 / \\
Y_{H, O 2}\end{array}$ & & $\begin{array}{l}(-1 / \\
Y_{H, O 2)} \\
* i_{S S, S T O} \\
+i_{S S, B M}\end{array}$ & $\begin{array}{r}\mu_{H}\left(\frac{S_{O 2}}{K_{O 2}+S_{O 2}}\right)\left(\frac{S_{N H 4}}{K_{N H 4}+S_{N H 4}}\right) \\
\left(\frac{S_{A L K}}{K_{A L K}+S_{A L K}}\right)\left(\frac{X_{S T O}}{X_{H}}\right)\left(K_{S T O}\right. \\
\left.+\frac{X_{S T O}}{X_{H}}\right) * X_{H}\end{array}$ \\
\hline 5 & & & $i_{N, B M}$ & $\begin{array}{l}-(1- \\
\left.Y_{H, N O X}\right) / \\
Y_{H, N O X}^{*} \\
(1 / \\
i_{N O X, N 2)}\end{array}$ & $\begin{array}{l}-(1- \\
\left.Y_{H, N O x}\right) / \\
Y_{H, N O x} * \\
(1 / \\
i_{N O x, N 2)}\end{array}$ & $\begin{array}{l}v_{5_{-} S_{N H} 4} \\
* i_{\text {charge }} \text { SNH } x+v_{5_{\text {SNOX }} i_{\text {charge_SNOX }}}\end{array}$ & & & & 1 & $\begin{array}{l}-1 / \\
Y_{H, N O X}\end{array}$ & & $\begin{array}{l}(-1 / \\
Y_{H, N O X)} \\
* i_{S S, S T O} \\
+i_{S S, B M}\end{array}$ & $\begin{array}{c}\mu_{H} * \eta O x \\
*\left(\frac{K_{O 2}}{K_{O 2}+S_{O 2}}\right)\left(\frac{S_{N O X}}{K_{N O X}+S_{N O X}}\right) \\
\left(\frac{S_{N H 4}}{K_{N H 4}+S_{N H 4}}\right) \\
\left(\frac{S_{A L K}}{K_{A L K}+S_{A L K}}\right)\left(\frac{X_{S T O}}{X_{H}}\right)\left(K_{S T O}\right. \\
\left.+\frac{X_{S T O}}{X_{H}}\right) * X_{H}\end{array}$ \\
\hline
\end{tabular}


Table 6 (Continiues). ASM3 Matrix Format (Adapted from Henze et al., 2000).

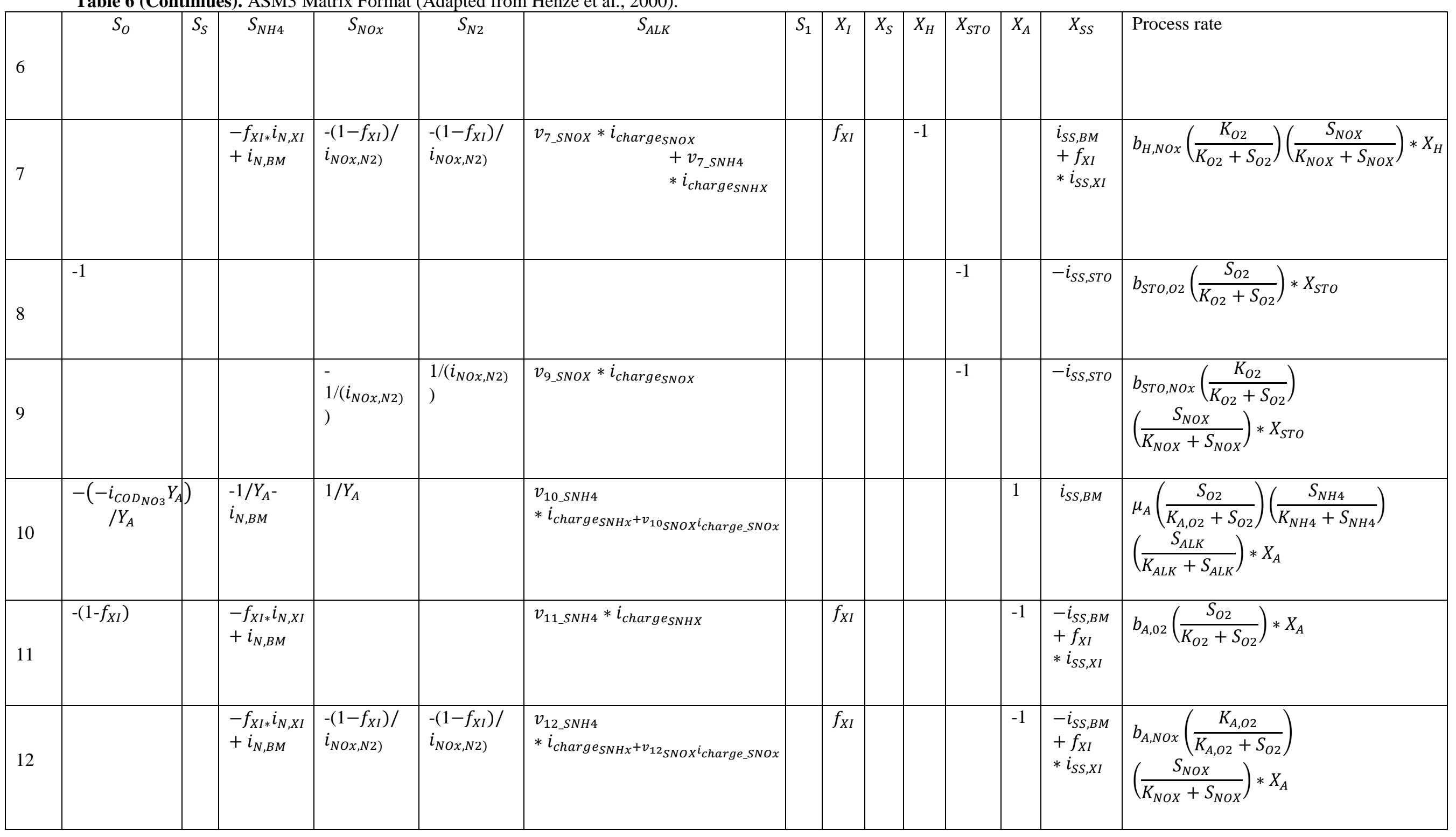


To understand the impact of initial values on model output, ASM1 model is run with four initial value combinations. The initial values of other parameters used in these four runs are given in Table 9. First, we run the model by setting $S_{O}$ and $S_{N O}$ to zero, as suggested by Table 8. Afterwards, we set $\mathrm{S}_{\mathrm{O}}$ to $2 \mathrm{~g} \mathrm{O}_{2} \mathrm{~m}^{-3}$ and take the second run. In the third run only $\mathrm{S}_{\mathrm{NO}}$ value is set to $5 \mathrm{~g} \mathrm{~N}$ $\mathrm{m}^{-3}$ whereas $\mathrm{S}_{\mathrm{O}}$ is given as $0 \mathrm{~g} \mathrm{O}_{2} \mathrm{~m}^{-3}$. In the final run, on the other hand, $\mathrm{S}_{\mathrm{O}}$ and $\mathrm{S}_{\mathrm{NO}}$ are set to $2 \mathrm{~g} \mathrm{O}_{2} \mathrm{~m}^{-3}$ and $5 \mathrm{~g}$ $\mathrm{N} \mathrm{m}^{-3}$ respectively.

Table 9. Numerical Experiments for ASM1 Model.

\begin{tabular}{lll}
\hline Run Number & $\mathbf{S}_{\mathbf{O}}$ & $\mathbf{S}_{\text {NO }}$ \\
\hline 1 & 0 & 0 \\
2 & 2 & 0 \\
3 & 0 & 5 \\
4 & 2 & 5
\end{tabular}

The motivation behind taking these simulations is to be able to observe the effect of oxygen and nitrate plus nitrite in the model when the other is not in place. Whereas in the final run, we aim to observe the combined effect of oxygen and nitrate plus nitrite.

When $\mathrm{S}_{\mathrm{O}}=0$ and $\mathrm{S}_{\mathrm{NO}}=0$ are taken as suggested in Table 8, we have the following observations:

a. Constant Ss with time: As shown in Figure 2, the concentration of the readily biodegradable substrate remains constant with time in the absence of oxygen and nitrate. This is because when SO and SNO are zero and the rates of processes affecting the change of Ss (aerobic and anoxic growth of heterotrophs and hydrolysis of entrapped organics) is cancelled in Table 3.

b. Increasing $\mathrm{Xs}$ and decreasing $\mathrm{XBH}$ and $\mathrm{XBA}$ : According to ASM1 model (Table 3), when $\mathrm{S}_{\mathrm{O}}=0$ and $\mathrm{SN}_{\mathrm{O}}=0$, the only process that does not cancel is the decay. As shown in Figure 3, slowly biodegradable substrate increases with time due to the decay of heterotrophs and autotrophs. Due to bh and ba decay rates, $\mathrm{X}_{\mathrm{BA}}$ and $\mathrm{X}_{\mathrm{BH}}$ decrease with time.

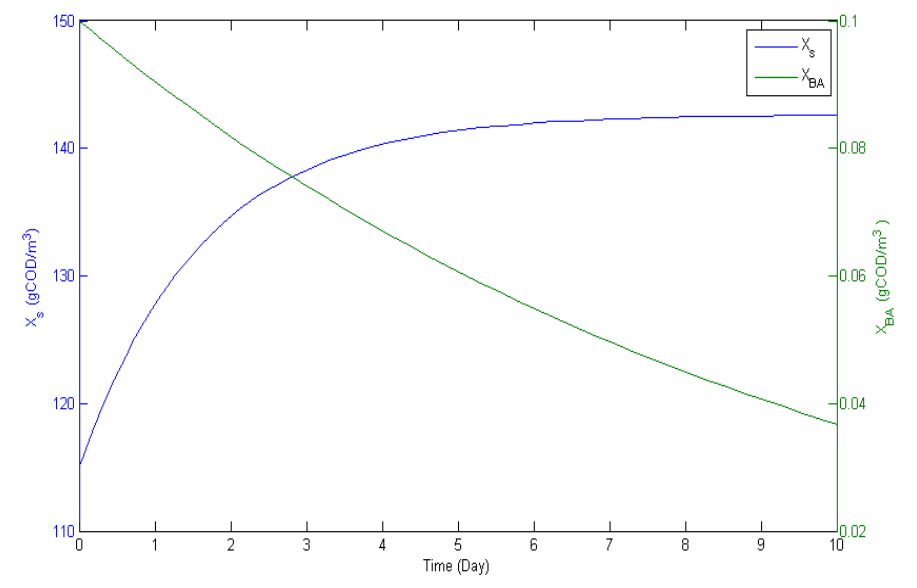

a

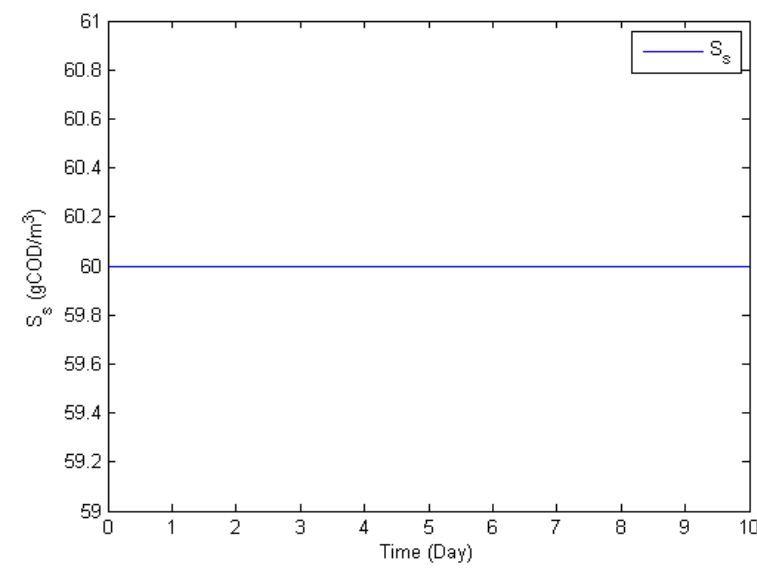

Figure 2. Variation of $\mathrm{S}_{\mathrm{s}}$ with time $\left(\mathrm{S}_{\mathrm{O}}=0\right.$ and $\left.\mathrm{S}_{\mathrm{NO}}=0\right)$.

c. Increasing $\mathrm{S}_{\mathrm{NH}}$ and decreasing $\mathrm{S}_{\mathrm{ND}}$ : In the ASM1 Ammonia nitrogen $\left(\mathrm{S}_{\mathrm{NH}}\right)$ is used in aerobic and anoxic growth of heterotrophs and aerobic growth of autotrophs and produced due to ammonification. Since growth mechanisms cancelled when $\mathrm{S}_{\mathrm{O}}=0$ and $\mathrm{S}_{\mathrm{NO}}=0$ the concentration increases due to ammonification. Soluble biodegradable organic nitrogen (SND) decreases due to ammonification increases due to hydrolysis of entrapped organic nitrogen but since the latter term cancels when

$\mathrm{S}_{\mathrm{O}}=0$ and $\mathrm{S}_{\mathrm{NO}}=0$, the reduction occurred due to ammonification alone.

d. Particulate biodegradable organic nitrogen $\left(\mathrm{X}_{\mathrm{ND}}\right)$ increases due to the decay of heterotroph and autotrophs. As explained previously, in order to understand the effect of oxygen and nitrate (plus nitrite) on the model behavior, the simulation model was run at four different conditions. The results of the comparative model behavior for $\mathrm{S}_{\mathrm{O}}=0$ and $\mathrm{S}_{\mathrm{NO}}=0, \mathrm{~S}_{\mathrm{O}}=2 \mathrm{~g} \mathrm{O}_{2} \mathrm{~m}^{-3}$ and $\mathrm{S}_{\mathrm{NO}}=0$, $\mathrm{S}_{\mathrm{NO}}=5 \mathrm{~g} \mathrm{~N} \mathrm{~m}^{-3}$ and $\mathrm{S}_{\mathrm{O}}=0$ and $\mathrm{S}_{\mathrm{O}}=2 \mathrm{gO}_{2} \mathrm{~m}^{-3}$ and $\mathrm{S}_{\mathrm{NO}}=5$ are given in Figures 6, 7 and 8 respectively.

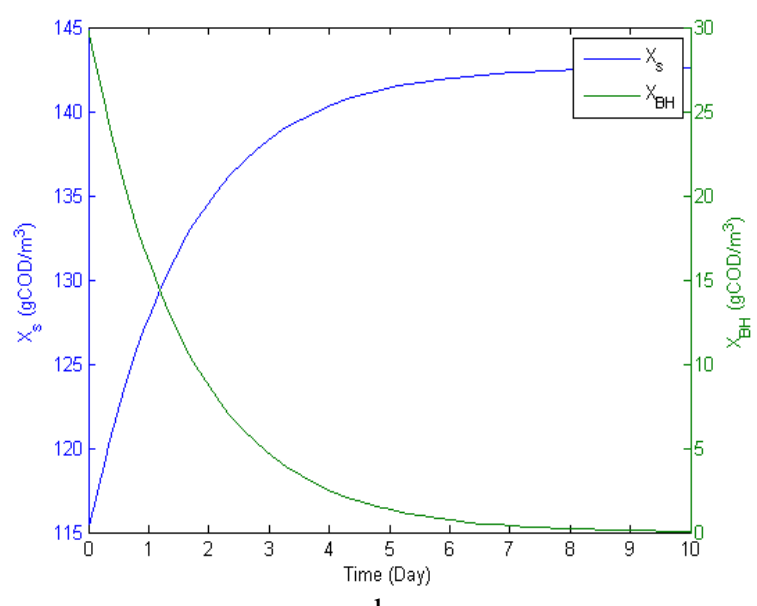

b

Figure 3. (a) Variation of $\mathrm{X}_{\mathrm{s}}$ and $\mathrm{X}_{\mathrm{BA}}$ with time, (b) Variation of $\mathrm{X}_{\mathrm{s}}$ and $\mathrm{X}_{\mathrm{BH}}$ with time $\left(\mathrm{S}_{\mathrm{O}}=0\right.$ and $\left.\mathrm{S}_{\mathrm{NO}}=0\right)$ 

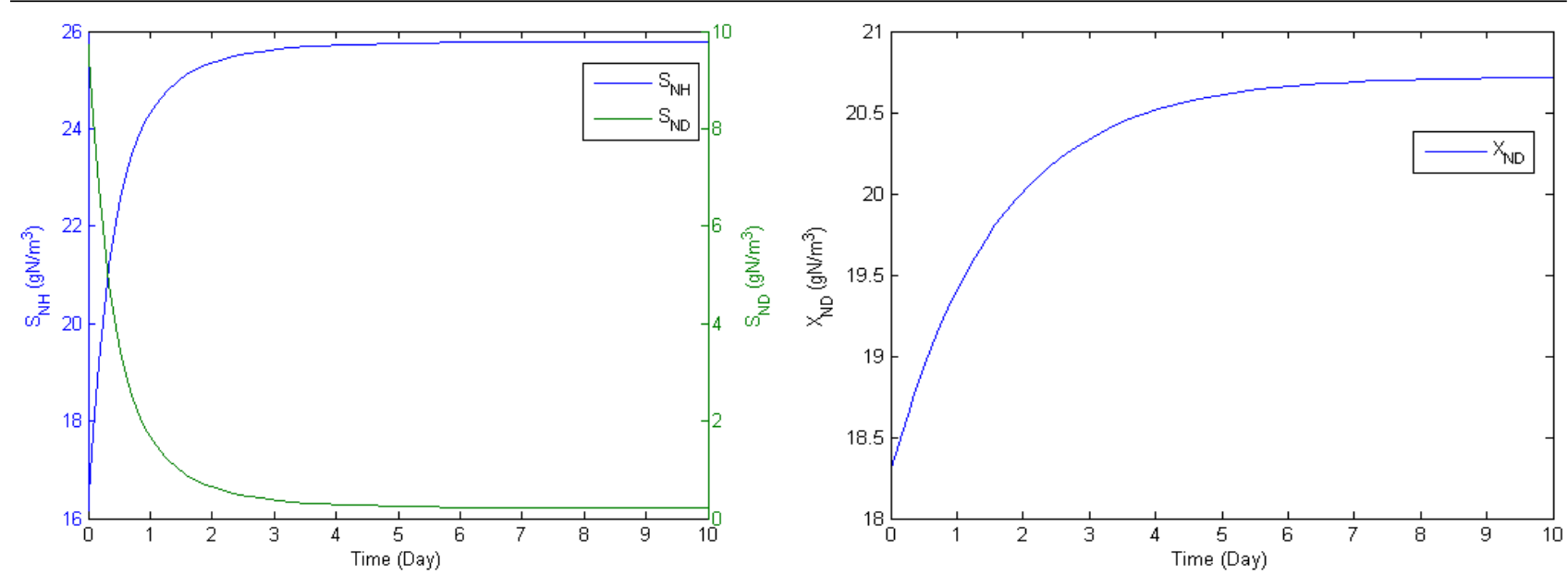

Figure 4. Variation of $S_{N H}$ and $S_{N D}$ with time $\left(S_{O}=0\right.$ and Figure 5. Variation of $X_{N D}$ with time $\left(S_{O}=0\right.$ and $\left.S_{N O}=0\right)$. $\left.\mathrm{S}_{\mathrm{NO}}=0\right)$.

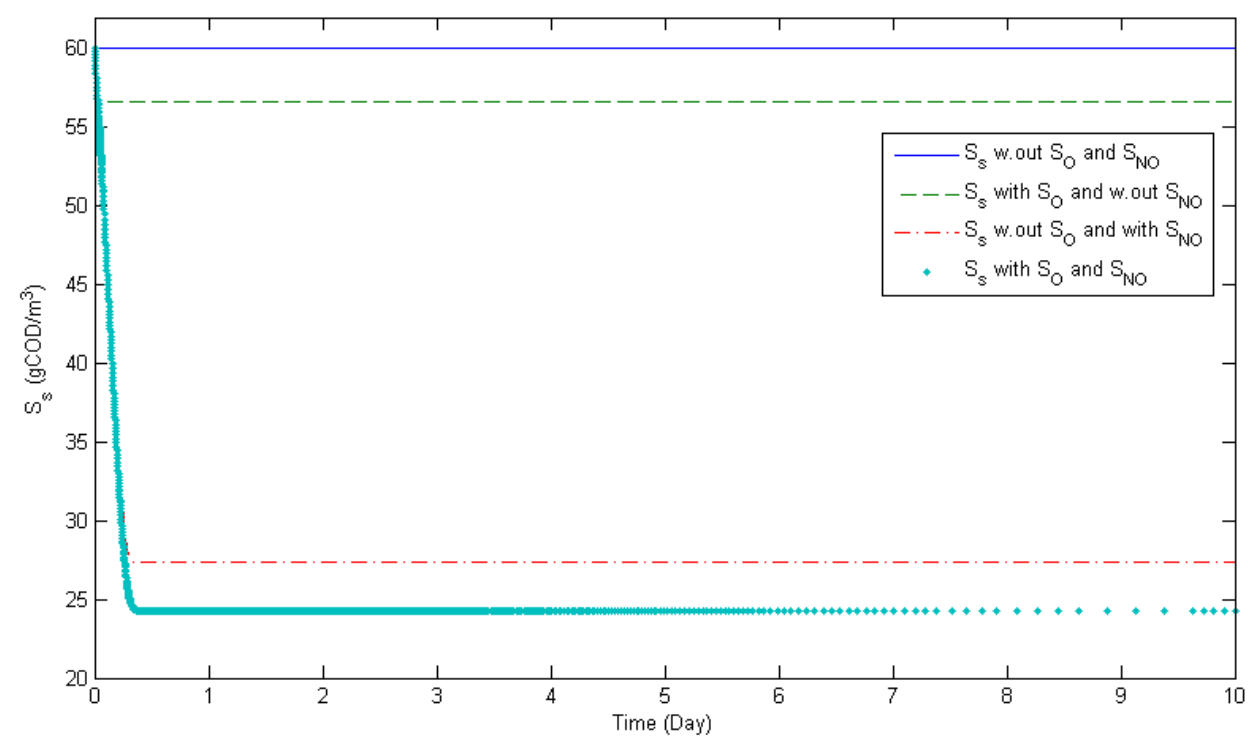

Figure 6. Variation of $\mathrm{S}_{\mathrm{s}}$ with time under four initial value combinations.

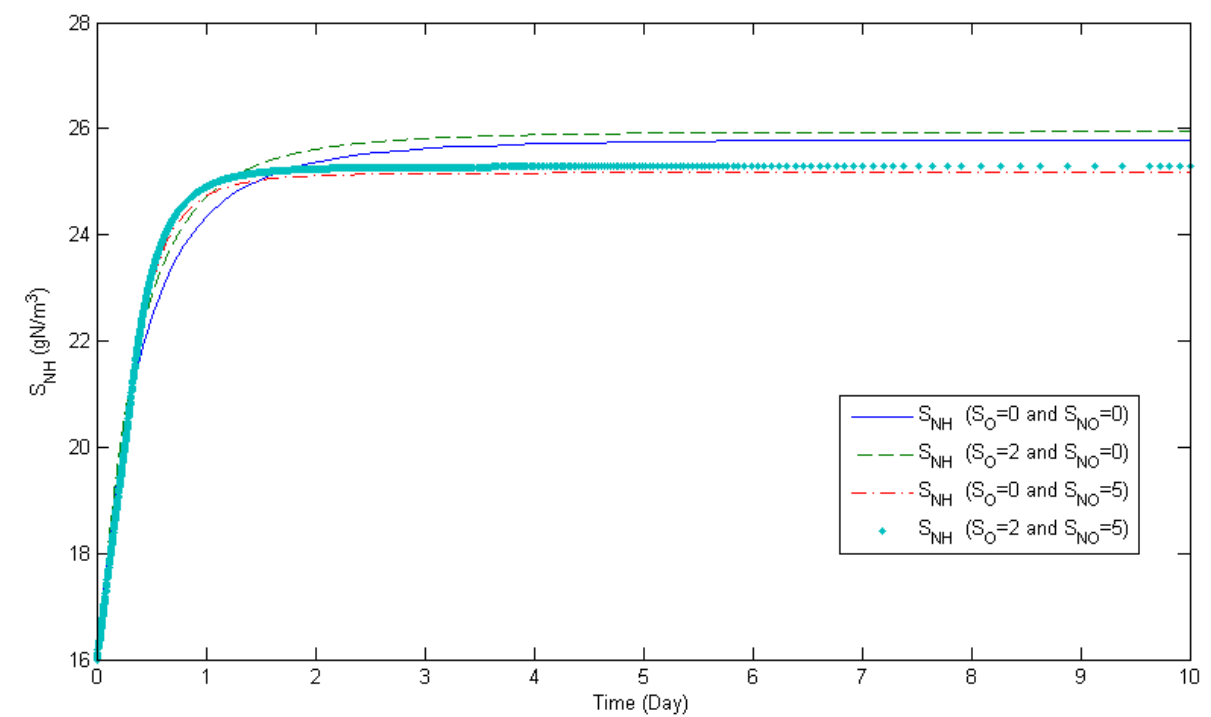

Figure 7. Variation of $\mathrm{S}_{\mathrm{NH}}$ with time under four initial value combinations.

We can see from Table 3 that processes affecting the change of $\mathrm{S}_{\mathrm{s}}$ are aerobic and anoxic growth of heterotrophs and hydrolysis of entrapped organics whereas $\mathrm{S}_{\mathrm{S}}$ remains constant in the first run (when $\mathrm{S}_{\mathrm{O}}=0$ and $\left.\mathrm{S}_{\mathrm{NO}}=0\right)$. Furthermore, Figure 6 shows that when
$\mathrm{S}_{\mathrm{O}}=2$ and $\mathrm{S}_{\mathrm{NO}}=0$ a little reduction occurs due to aerobic growth of autotrophs and heterotrophs before the system reaches its equilibrium whereas oxygen is depleted very quickly. The $S_{s}$ reduction increases when $S_{O}=0$ and $\mathrm{S}_{\mathrm{NO}}=5$ (the third run in Table 9) due to anoxic growth of 
heterotrophs. The highest reduction in $\mathrm{S}_{\mathrm{s}}$ occurs when $\mathrm{S}_{\mathrm{O}}$ and $S_{\mathrm{NO}}$ are set to $2 \mathrm{~g} \mathrm{O}_{2} \mathrm{~m}^{-3}$ and $5 \mathrm{~g} \mathrm{~N} \mathrm{~m}^{-3}$ respectively. This expected result since every process affecting the change of readily biodegradable substrate consumption rate in Table 3 takes place. Figure 7 . shows the variation

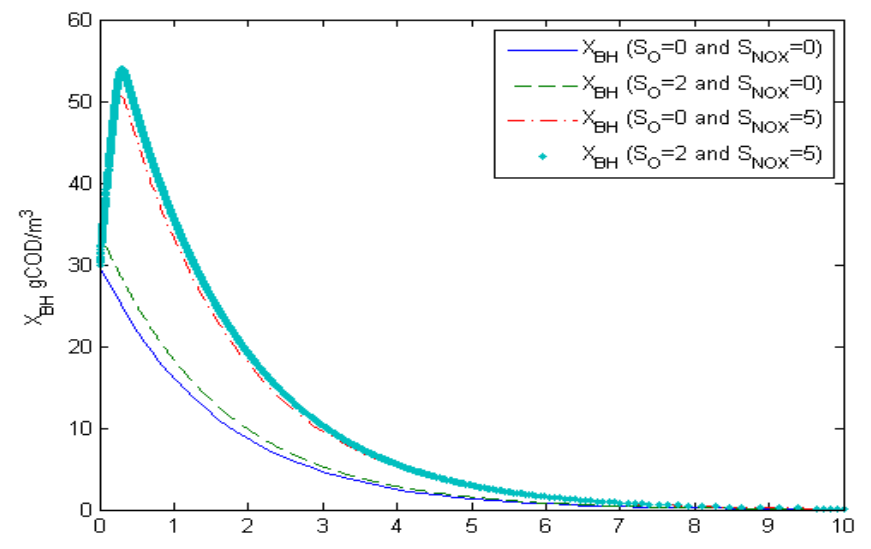

a of $\mathrm{S}_{\mathrm{NH}}$ with time under the four initial value combinations. Similarly, the changes result from aerobic and anoxic growth of heterotrophs and aerobic growth of autotrophs.

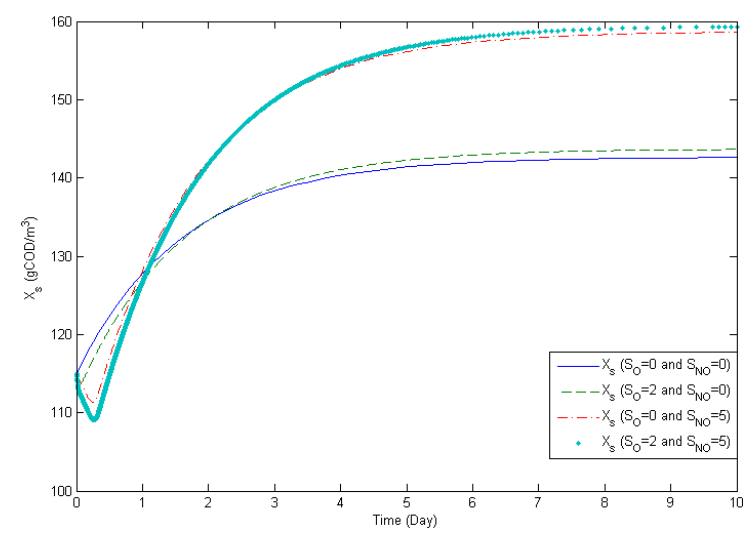

b

Figure 8. Variation of $\mathrm{X}_{\mathrm{BH}}(\mathrm{a})$ and $\mathrm{X}_{\mathrm{S}}(\mathrm{b})$ with time under four initial value combinations.
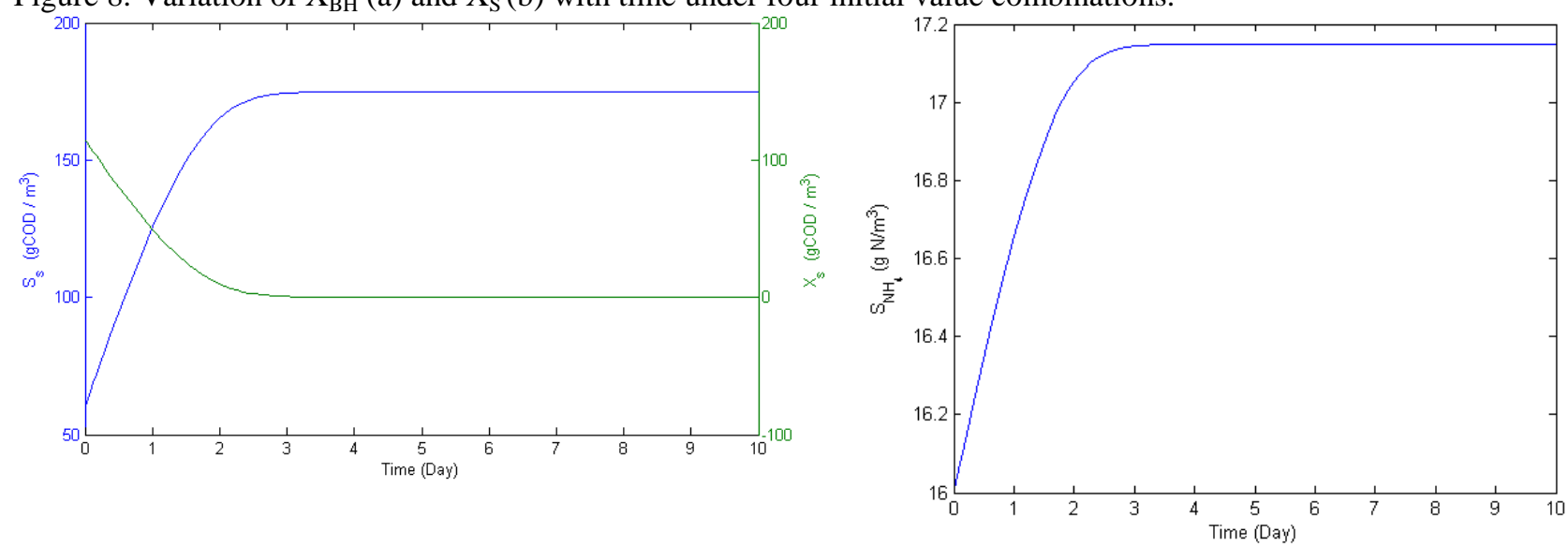

Figure 9. Variation of $S_{\mathrm{s}}$ and $\mathrm{X}_{\mathrm{S}}$ with time $\left(\mathrm{S}_{\mathrm{O}}=0\right.$ and $\left.\mathrm{S}_{\mathrm{NO}}=0\right)$.

Variation of slowly biodegradable substrate with time under four initial conditions are represented in Figure 8. Before the consumption of oxygen and nitrate (plus nitrite) concentration of the heterotrophic biomass increases due to aerobic and anoxic growth of heterotrophs. In the absence of oxygen and nitrate (and nitrite) due to $b_{h}$ and $b_{a}$ decay rates, $X_{B A}$ and $X_{B H}$ decrease with time. Also, the increase in the presence of oxygen and nitrate (Figure $8(\mathrm{~b})$ ) is mainly due to the change in $\mathrm{X}_{\mathrm{BH}}$ concentration.

\section{Simulation of ASM3 Model}

In order to analyze the behavior of ASM3 model, we take runs using the same initial values (Table 9) together with typical parameter values, rate equations and their coefficients (Table 6 and Table 10). The same wastewater composition is used for the comparison of the model outputs (Table 7).

In the first run $\left(S_{O}=0\right.$ and $\left.S_{N O}=0\right)$, we have the following observations:

Figure 10. Variation of $\mathrm{S}_{\mathrm{NH} 4}$ with time $\left(\mathrm{S}_{\mathrm{O}}=0\right.$ and $\left.\mathrm{S}_{\mathrm{NO}}=0\right)$.

a. Decrease in $S_{s}$ and increase in $X_{s}$ over time: The only process taking place is hydrolysis. As shown in Figure 9, the concentration of the readily biodegradable substrate increases due to hydrolysis and then reaches its equilibrium. This is because when $S_{O}$ and $S_{N O}$ are zero the rates of other processes affecting the change of $S_{s}$ (aerobic and anoxic growth of heterotrophs) cancel in Table 6.

b. Increase in $\mathrm{S}_{\mathrm{NH} 4}$ due to hydrolysis.

Variation of $\mathrm{S}_{\mathrm{NH} 4}$ with time is shown in Figure 10 for $\mathrm{S}_{\mathrm{O}}=0$ and $\mathrm{S}_{\mathrm{NO}}=0$.

The results of the comparative model behavior for $\mathrm{S}_{\mathrm{O}}=0$ and $\mathrm{S}_{\mathrm{NO}}=0, \mathrm{~S}_{\mathrm{O}}=2$ and $\mathrm{S}_{\mathrm{NO}}=0, \mathrm{~S}_{\mathrm{NO}}=5$ and $\mathrm{S}_{\mathrm{O}}=0$ and $\mathrm{S}_{\mathrm{O}}=2$ and $\mathrm{S}_{\mathrm{NO}}=5$ are shown in Figure 11, 12 and 13, respectively. Figure 11 show that readily biodegradable substrate is initially used in growth processes in the presence of oxygen. When the oxygen is consumed the $\mathrm{S}_{\mathrm{s}}$ concentration increases due to hydrolysis. 
Table 10. Typical values of kinetic parameters for ASM3 (Gujer et al., 1999).

\begin{tabular}{|c|c|c|}
\hline Symbol & Unit & Value at $20^{\circ} \mathrm{C}$ \\
\hline $\mathrm{k}_{\mathrm{H}}$ & $\mathrm{gCOD}_{\mathrm{Xs}}\left(\mathrm{gCOD}_{\mathrm{XH}}\right)^{-1} \mathrm{~d}^{-1}$ & 3 \\
\hline $\mathrm{K}_{\mathrm{X}}$ & $\mathrm{gCOD}_{\mathrm{Xs}}\left(\mathrm{gCOD}_{\mathrm{XH}}\right)^{-1}$ & 1 \\
\hline \multicolumn{3}{|c|}{$\begin{array}{l}\text { Heterotrophic organisms } \mathrm{X}_{\mathrm{H}} \text {, aerobic an } \\
\text { activity }\end{array}$} \\
\hline $\mathrm{k}_{\mathrm{STO}}$ & $\mathrm{gCOD}_{\mathrm{Ss}}\left(\mathrm{gCOD}_{\mathrm{XH}}\right)^{-1} \mathrm{~d}^{-1}$ & 5 \\
\hline$\eta_{\text {NOX }}$ & - & 0.6 \\
\hline $\mathrm{K}_{\mathrm{O} 2}$ & $\mathrm{gO}_{2} \mathrm{~m}^{-3}$ & 0.2 \\
\hline $\mathrm{K}_{\mathrm{NOX}}$ & $\mathrm{gNO}_{3-\mathrm{N}} \mathrm{m}^{-3}$ & 0.5 \\
\hline $\mathrm{K}_{\mathrm{S}}$ & $\mathrm{gCOD}_{\mathrm{Ss}} \mathrm{m}^{-3}$ & 2 \\
\hline $\mathrm{K}_{\mathrm{STO}}$ & $\mathrm{gCOD}_{\mathrm{XSTO}}\left(\mathrm{gCOD}_{\mathrm{XH}}\right)^{-1}$ & 1 \\
\hline$\mu_{\text {Hmax }}$ & $\mathrm{d}^{-1}$ & 2 \\
\hline $\mathrm{K}_{\mathrm{NH} 4}$ & $\mathrm{gN} \mathrm{m}^{-3}$ & 0.01 \\
\hline $\mathrm{K}_{\mathrm{ALK}}$ & mole $\mathrm{HCO}_{3} \mathrm{~m}^{-3}$ & 0.1 \\
\hline $\mathrm{b}_{\mathrm{H}, \mathrm{O} 2}$ & $\mathrm{~d}^{-1}$ & 0.2 \\
\hline$b_{\mathrm{H}, \mathrm{NOX}}$ & $\mathrm{d}^{-1}$ & 0.1 \\
\hline $\mathrm{b}_{\mathrm{STO}, \mathrm{O} 2}$ & $\mathrm{~d}^{-1}$ & 0.2 \\
\hline$b_{\text {STO,NOX }}$ & $d^{-1}$ & 0.1 \\
\hline
\end{tabular}

Autotrophic organismss XA, nitrifying activity

\begin{tabular}{lll}
$\mu_{\mathrm{Amax}}$ & $\mathrm{d}^{-1}$ & 1 \\
$\mathrm{~K}_{\mathrm{A}, \mathrm{NH} 4}$ & $\mathrm{gN} \mathrm{m}^{-3}$ & 1 \\
$\mathrm{~K}_{\mathrm{A}, \mathrm{O} 2}$ & $\mathrm{gO}_{2} \mathrm{~m}^{-3}$ & 0.5 \\
$\mathrm{~K}_{\mathrm{A}, \mathrm{ALK}}$ & ${\mathrm{mole} \mathrm{HCO}_{3} \mathrm{~m}^{-3}}^{\mathrm{b}_{\mathrm{A}, \mathrm{O} 2}}$ & 0.5 \\
$\mathrm{~b}_{\mathrm{A}, \mathrm{NOX}}$ & $\mathrm{d}^{-1}$ & 0.15 \\
\hline
\end{tabular}

Variation of $\mathrm{X}_{\mathrm{H}}$ in time under four initial value combinations is shown in Figure 12. The processes that change the $X_{H}$ concentration are aerobic growth of heterotrophs, anoxic growth of denitrifiers, aerobic and anoxic endogenous respiration of heterotrophs. Since all

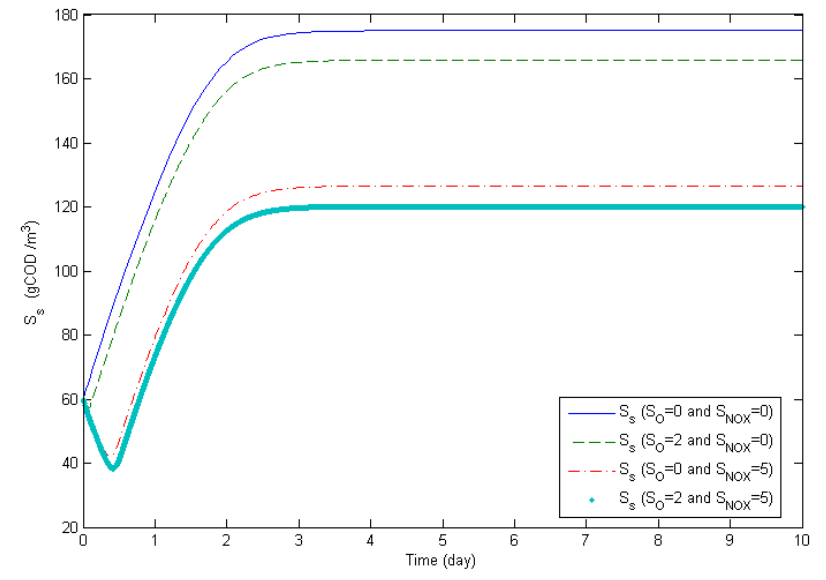

Figure 11. Variation of $\mathrm{S}_{\mathrm{s}}$ with time under four initial value combinations. these processes cancel when $S_{O}=0$ and $S_{N O}=0$ the $X_{H}$ remains constant. The highest increase is observed in the presence of oxygen and nitrate \& nitrite due to both aerobic and anoxic growth.

Variation of $\mathrm{X}_{\text {STO }}$ in time under four initial value combinations is shown in Figure 13. Processes that change the $\mathrm{X}_{\mathrm{STO}}$ concentration are aerobic and anoxic storage of $\mathrm{S}_{\mathrm{S}}$ (increases storage), aerobic growth of heterotrophs and anoxic growth of denitrifies (decreases storage), aerobic and anoxic endogenous respiration of STO (decreases). Since all these processes cancel when $\mathrm{S}_{\mathrm{O}}=0$ and $\mathrm{S}_{\mathrm{NO}}=0$ the $\mathrm{X}_{\mathrm{STO}}$ remains constant. The highest increase is observed in the presence of oxygen and nitrate since both aerobic and anoxic storage occurs.

\section{Sensitivity Analysis}

In this part of the study, we analyzed the sensitivity of biodegradable substrate (SS) concentration to model parameters using a one-at-a-time sampling approach. Specifically, at each simulation run base value of a parameter is increased (or decreased) by $25 \%$. The design matrix of these simulation experiments is given in Table 11 for a hypothetical model with 6 parameters. The real design sampling matrices are given in the Appendix B. ASM1 model consists of 19 parameters which lead to 39 simulation experiments whereas ASM3 has 22 parameters which lead to 45 simulation runs. In each simulation run, we obtain the equilibrium level of variable which constitutes the dependent variable of the each meta-model used in our sensitivity analysis.

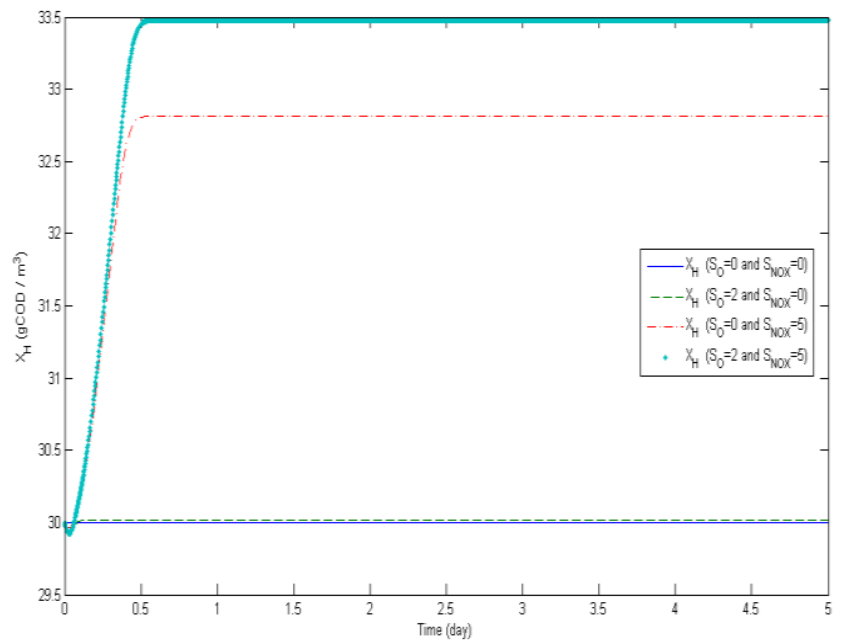

Figure 12. Variation of $\mathrm{X}_{\mathrm{H}}$ with time under four initial value combinations. 


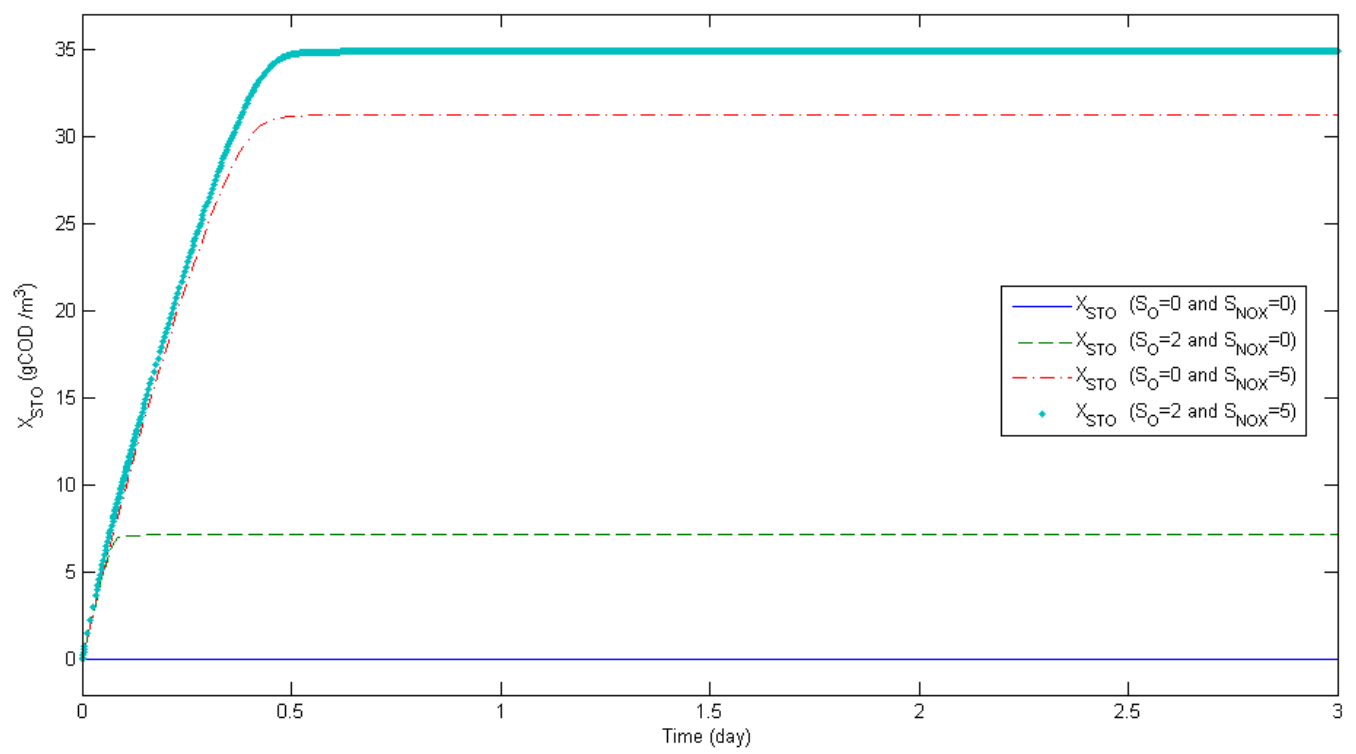

Figure 13. Variation of $\mathrm{X}_{\text {STO }}$ with time under four initial value ombinations

In order to provide a formal measure for parameter sensitivity of Ss, we utilize standardized regression coefficients in this study. Each simulation experiment with dependent variable values is taken into $\mathrm{R}$ and a regression model is built. In the next step, standardized regression coefficients are calculated. In the literature, standardized regression coefficients are utilized by Hekimoğlu and Barlas (2018) for parameter sensitivity of higher-order differential equation models. Standardized regression coefficients' magnitudes signify the importance of an independent variable for the simulation output (the equilibrium level of Ss model). It is closely related to partial correlation coefficients in the literature (Draper and Smith, 1998). The results of regression models for sensitivity simulations of ASM1 and ASM3 are presented in Table 12 and Table 13 respectively.

The results of the analysis for ASM1 showed that the variation of $S_{S}$ is sensitive to $Y_{H}, \mu_{H, m a x}, k_{H}, n_{g}, n_{h}$ and $K_{s}$. This is in agreement with the literature, as the results of a study conducted by Ghorbani and Eskicioglu (2011) also indicate the sensitivity of ASM1 to these parameters. The results are presented in decreasing order in Table 12.

Table 11. Design of Experiments Matrix for Sensitivity Simulations.

\begin{tabular}{|c|c|c|c|c|c|c|}
\hline \multirow[b]{2}{*}{ Experiment } & \multicolumn{6}{|c|}{ Parameter } \\
\hline & 1 & 2 & 3 & 4 & 5 & 6 \\
\hline Base & 1 & 1 & 1 & 1 & 1 & 1 \\
\hline 1 & 0.75 & 1 & 1 & 1 & 1 & 1 \\
\hline 2 & 1.25 & 1 & 1 & 1 & 1 & 1 \\
\hline 3 & 1 & 0.75 & 1 & 1 & 1 & 1 \\
\hline 4 & 1 & 1.25 & 1 & 1 & 1 & 1 \\
\hline 5 & 1 & 1 & 0.75 & 1 & 1 & 1 \\
\hline 6 & 1 & 1 & 1.25 & 1 & 1 & 1 \\
\hline 7 & 1 & 1 & 1 & 0.75 & 1 & 1 \\
\hline 8 & 1 & 1 & 1 & 1.25 & 1 & 1 \\
\hline 9 & 1 & 1 & 1 & 1 & 0.75 & 1 \\
\hline 10 & 1 & 1 & 1 & 1 & 1.25 & 1 \\
\hline 11 & 1 & 1 & 1 & 1 & 1 & 0.75 \\
\hline 12 & 1 & 1 & 1 & 1 & 1 & 1.25 \\
\hline
\end{tabular}


Table 12. Regression Coefficients for Senstivity Simulations of ASM1 Model.

\begin{tabular}{|c|c|c|c|}
\hline $\begin{array}{l}\text { Coefficient } \\
\text { Name } \\
\end{array}$ & $\begin{array}{l}\text { Regression } \\
\text { Coefficient }\end{array}$ & $\begin{array}{l}\text { Standardized Regression } \\
\text { Coefficient }\end{array}$ & $\begin{array}{l}\text { Absolute Standardized } \\
\text { Coefficients }\end{array}$ \\
\hline$Y_{H}$ & -55.662 & -0.87981 & 0.879808 \\
\hline$\mu_{\mathrm{H}, \max }$ & -13.4396 & -0.21243 & 0.21243 \\
\hline $\mathrm{k}_{\mathrm{H}}$ & 12.6632 & 0.200158 & 0.200158 \\
\hline$n_{g}$ & -10.9102 & -0.17245 & 0.172449 \\
\hline$n_{h}$ & 10.278 & 0.162457 & 0.162457 \\
\hline $\mathrm{K}_{\mathrm{s}}$ & 4.1786 & 0.066048 & 0.066048 \\
\hline $\mathrm{K}_{\mathrm{x}}$ & -0.1448 & -0.00229 & 0.002289 \\
\hline$b_{H}$ & 0.0162 & 0.000256 & 0.000256 \\
\hline $\mathrm{Y}_{\mathrm{A}}$ & -0.0064 & -0.0001 & 0.000101 \\
\hline$\mu_{\mathrm{A}, \max }$ & 0.0032 & $5.06 \mathrm{E}-05$ & $5.06 \mathrm{E}-05$ \\
\hline $\mathrm{K}_{\mathrm{OH}}$ & 0.0032 & $5.06 \mathrm{E}-05$ & $5.06 \mathrm{E}-05$ \\
\hline $\mathrm{K}_{\mathrm{NO}}$ & 0.0024 & $3.79 \mathrm{E}-05$ & $3.79 \mathrm{E}-05$ \\
\hline $\mathrm{K}_{\mathrm{OA}}$ & -0.001 & $-1.58 \mathrm{E}-05$ & $1.58 \mathrm{E}-05$ \\
\hline$f_{p}$ & -0.0004 & $-6.32 \mathrm{E}-06$ & $6.32 \mathrm{E}-06$ \\
\hline $\mathrm{b}_{\mathrm{a}}$ & $5.65 \mathrm{E}-15$ & 8.93E-17 & $8.93 \mathrm{E}-17$ \\
\hline$i_{\text {xe }}$ & $5.02 \mathrm{E}-15$ & $7.94 \mathrm{E}-17$ & $7.94 \mathrm{E}-17$ \\
\hline $\mathrm{k}_{\mathrm{a}}$ & $4.40 \mathrm{E}-15$ & $6.95 \mathrm{E}-17$ & $6.95 \mathrm{E}-17$ \\
\hline $\mathrm{i}_{\mathrm{XB}}$ & $2.51 \mathrm{E}-15$ & $3.97 \mathrm{E}-17$ & $3.97 \mathrm{E}-17$ \\
\hline $\mathrm{K}_{\mathrm{NH}}$ & $-8.29 \mathrm{E}-31$ & $-1.31 \mathrm{E}-32$ & $1.31 \mathrm{E}-32$ \\
\hline
\end{tabular}

Table 13. Regression Coefficients for Senstivity Simulations of ASM3 Model.

\begin{tabular}{|c|c|c|c|}
\hline $\begin{array}{l}\text { Coefficient } \\
\text { Name } \\
\end{array}$ & Regression Coefficient & Standardized Regression Coefficient & Absolute Standardized Coefficients \\
\hline $\mathrm{K}_{\mathrm{STO}}$ & -12.264 & -0.67975 & 0.679746 \\
\hline$\mu_{\mathrm{Hmax}}$ & 8.2386 & 0.456634 & 0.456634 \\
\hline $\mathrm{n}_{\mathrm{NOX}}$ & 8.2386 & 0.456634 & 0.456634 \\
\hline $\mathrm{k}_{\mathrm{STO}}$ & -5.103 & -0.28284 & 0.28284 \\
\hline $\mathrm{b}_{\mathrm{H}, \mathrm{NOX}}$ & 2.5082 & 0.13902 & 0.13902 \\
\hline $\mathrm{b}_{\mathrm{STO}, \mathrm{NOX}}$ & 1.4978 & $8.30 \mathrm{E}-02$ & 0.083017 \\
\hline $\mathrm{K}_{\mathrm{s}}$ & 0.4908 & 0.027203 & 0.027203 \\
\hline $\mathrm{k}_{\mathrm{H}}$ & -0.1954 & -0.01083 & 0.01083 \\
\hline $\mathrm{K}_{\mathrm{ALK}}$ & -0.1516 & $-8.40 \mathrm{E}-03$ & 0.008403 \\
\hline $\mathrm{K}_{\mathrm{x}}$ & 0.0438 & 0.002428 & 0.002428 \\
\hline $\mathrm{K}_{\mathrm{NOX}}$ & -0.0316 & -0.00175 & 0.001751 \\
\hline $\mathrm{K}_{\mathrm{NH} 4}$ & -0.0048 & $-2.66 \mathrm{E}-04$ & 0.000266 \\
\hline $\mathrm{b}_{\mathrm{A}, \mathrm{NOX}}$ & 0.0038 & $2.11 \mathrm{E}-04$ & 0.000211 \\
\hline $\mathrm{K}_{\mathrm{A}, \mathrm{NOX}}$ & -0.0008 & $-4.43 \mathrm{E}-05$ & $4.43 \mathrm{E}-05$ \\
\hline $\mathrm{K}_{\mathrm{A}, \mathrm{NH} 4}$ & $-1.18 \mathrm{E}-15$ & $-6.53 \mathrm{E}-17$ & $6.53 \mathrm{E}-17$ \\
\hline $\mathrm{K}_{\mathrm{A}, \mathrm{O} 2}$ & $-1.10 \mathrm{E}-15$ & $-6.09 \mathrm{E}-17$ & $6.09 \mathrm{E}-17$ \\
\hline$\mu_{\mathrm{A}, \max }$ & $-1.10 \mathrm{E}-15$ & $-6.09 \mathrm{E}-17$ & $6.09 \mathrm{E}-17$ \\
\hline$b_{\mathrm{HO} 2}$ & $-7.61 \mathrm{E}-16$ & $-4.22 \mathrm{E}-17$ & $4.22 \mathrm{E}-17$ \\
\hline $\mathrm{K}_{\mathrm{A}, \mathrm{ALK}}$ & $-7.51 \mathrm{E}-16$ & $-4.16 \mathrm{E}-17$ & $4.16 \mathrm{E}-17$ \\
\hline $\mathrm{b}_{\mathrm{A}, \mathrm{O} 2}$ & $-7.46 \mathrm{E}-16$ & $-4.13 \mathrm{E}-17$ & 4.13E-17 \\
\hline $\mathrm{K}_{\mathrm{O} 2}$ & $-7.41 \mathrm{E}-16$ & $-4.11 \mathrm{E}-17$ & $4.11 \mathrm{E}-17$ \\
\hline$b_{\mathrm{STO}, \mathrm{O} 2}$ & $4.71 \mathrm{E}-16$ & $2.61 \mathrm{E}-17$ & $2.61 \mathrm{E}-17$ \\
\hline
\end{tabular}




\section{Conclusion}

The major applications of white-box wastewater treatment plant models include learning, design and process optimization. The development of the ASM models by the International Water Association was a milestone enabling a deeper understanding of biochemical processes taking place during wastewater treatment. The models were developed primarily considering urban wastewater systems, but can be readily applied to different conditions, such as industrial wastewater treatment.

Even to this day, the ASM1 model remains the state of the art for modeling activated sludge systems. ASM3 has been introduced to fix ASM1 deficiencies and implement a new framework for modeling based on ASM. The biggest difference of ASM3 from ASM1 is that the significance of storage polymers in heterotrophic activated sludge conversions is considered in ASM3. The descriptions of anaerobic processes are not involved in ASM1 and ASM3. Their use is restricted to aerobic and anoxic conditions. The introduction of ASM3 aimed to correct the defects of ASM1 and presented a new standard for ASM based modeling. The major difference between the ASM1 and ASM3 models is that the latter recognizes the importance of storage polymers in the heterotrophic activated sludge conversions. Hence, these models can be applied only to aerobic and anoxic conditions. Our literature review also reveals that parameter sensitivity analysis of ASM models is a research gap in the literature. Although there are numerous studies on different aspects and applications of this model family, no formal sensitivity analysis study has been done so far.

The implications of using one model over another depend on the configurations and specific factors of the treatment plant being studied. Therefore, comparison of the outcomes of these models deemed necessary to determine the impact of various modeling processes. In the second part of the study, ASM1 and ASM3 models are simulated in MATLAB with different initial values in order to develop more insight into the model structure. In these simulations, $S_{O}$ and $S_{N O}$ are found to be the critical components in the systems.

In the third part of the study, a basic sensitivity analysis was conducted for ASM1 and ASM3 considering readily biodegradable substrate $\left(\mathrm{S}_{\mathrm{S}}\right)$ concentration. Standardized regression coefficients were used to determine the parameter sensitivity of the model output. Our results showed that $\mathrm{Y}_{\mathrm{H}}, \mu_{\mathrm{H}, \max }, \mathrm{k}_{\mathrm{H}}, \mathrm{n}_{\mathrm{g}}, \mathrm{n}_{\mathrm{h}}$ and $\mathrm{K}_{\mathrm{s}}$ parameters are found to be important in ASM1 model whereas $\mathrm{K}_{\mathrm{STO}}$, $\mu_{\mathrm{Hmax}}, n_{\mathrm{NOX}}, \mathrm{k}_{\mathrm{STO}}$ and $\mathrm{b}_{\mathrm{H}, \mathrm{NOX}}$ parameters are important for ASM3.

Extension of the sensitivity analysis to other variables in both models using a design matrix that considers interactions between parameters, such as central composite design or Taguchi methods is left to future research.

\section{Acknowledgement}

Başak Savun-Hekimoğlu is a post-doctoral researcher at Istanbul University, Institute of Marine Sciences and Management. The author is thankful to the Istanbul University Research Fund (BAP) for post-doctoral scholarship granted with an identity number MAB-201934967.

\section{References}

Brdjanovic, D., Meijer, S. C., Lopez-Vazquez, C. M., Hooijmans, C. M., van Loosdrecht, M. C. (Eds.). (2015). Applications of activated sludge models. Iwa Publishing.

Brun, R., Kühni, M., Siegrist, H., Gujer, W., Reichert, P. (2002). Practical identifiability of ASM2d parameters - systematic selection and tuning of parameter subsets. Water research, 36(16), 41134127.

Choubert, J. M., Stricker, A. E., Marquot, A., Racault, Y., Gillot, S., Héduit, A. (2009). Updated Activated Sludge Model $\mathrm{n}^{\circ} 1$ Parameter Values for Improved Prediction of Nitrogen Removal in Activated Sludge Processes: Validation at 13 Full- scale Plants. Water Environment Research, 81(9), 858-865.

Copp, J. B., Spanjers, H., Vanrolleghem, P. A. (Eds.). (2002). Respirometry in control of the activated sludge process: benchmarking control strategies (No. 11). IWA publishing.

Draper, N. R., Smith, H. (1998). Applied regression analysis (Vol. 326). John Wiley \& Sons.

Drewnowski, J., Szeląg, B., Xie, L., Lu, X., Ganesapillai, M., Deb, C. K., Lagód, G. (2020). The Influence of COD Fraction Forms and Molecules Size on Hydrolysis Process Developed by Comparative OUR Studies in Activated Sludge Modelling. Molecules, 25(4), 929.

Gernaey, K. V., van Loosdrecht, M. C., Henze, M., Lind, M., Jørgensen, S. B. (2004). Activated sludge wastewater treatment plant modelling and simulation: state of the art. Environmental Modelling \& Software, 19(9), 763-783.

Ghorbani, M., Eskicioglu, C. (2011). Application of the International Water Association activated sludge models to describe aerobic sludge digestion. Environmental technology, 32(16), 1923-1938.

Gujer, W. (2008). Transformation Processes. Systems Analysis for Water Technology, 77-100.

Guisasola, A., Sin, G., Baeza, J. A., Carrera, J., Vanrolleghem, P. A. (2005). Limitations of ASM1 and ASM3: a comparison based on batch oxygen uptake rate profiles from different full-scale wastewater treatment plants. Water Science and Technology, 52(10-11), 69-77.

Hauduc, H., Rieger, L., Oehmen, A., Van Loosdrecht, M. C. M., Comeau, Y., Héduit, A. Gillot, S. (2013). Critical review of activated sludge modeling: state of process knowledge, modeling concepts, and limitations. Biotechnology and Bioengineering, 110(1), 24-46.

Hauduc, H., Rieger, L., Oehmen, A., Van Loosdrecht, M. C. M., Comeau, Y., Héduit, A., Gillot, S. (2013). 
Critical review of activated sludge modeling: state of process knowledge, modeling concepts, and limitations. Biotechnology and Bioengineering, 110(1), 24-46.

Hauduc, H., Rieger, L., Takács, I., Héduit, A., Vanrolleghem, P. A., Gillot, S. (2010). A systematic approach for model verification: application on seven published activated sludge models. Water Science and Technology, 61(4), 825-839.

Hekimoğlu, M., Barlas, Y. (2016). Sensitivity analysis for models with multiple behavior modes: a method based on behavior pattern measures. System Dynamics Review, 32(3-4), 332-362.

Henze, M., Grady Jr, C. L., Gujer, W., Marais, G. V. R., Matsuo, T. (1987). A general model for single-sludge wastewater treatment systems. Water research, 21(5), 505-515.

Henze, M., Gujer, W., Mino, T., van Loosdrecht, M. C. (2000). Activated sludge models ASM1, ASM2, ASM2d and ASM3. IWA publishing.

Van Loosdrecht, M. C. M., Lopez-Vazquez, C. M., Meijer, S. C. F., Hooijmans, C. M., Brdjanovic, D. (2015). Twenty-five years of ASM1: past, present and future of wastewater treatment modelling. Journal of Hydroinformatics, 17(5), 697-718.

Makinia, J., Zaborowska, E. (2020). Mathematical modelling and computer simulation of activated sludge systems. IWA publishing.

Mhlanga, F. T. (2008). Modelling of the Marianridge Wastewater Treatment Plant (Doctoral dissertation, University of KwaZulu-Natal, Durban).

Mulas, M. (2006). Modelling and control of activated sludge processes. Università degli Studi di Cagliari.

Mussati, M., Gernaey, K., Gani, R., \& Jørgensen, S. (2002). Computer aided model analysis and dynamic simulation of a wastewater treatment plant. Clean technologies and environmental policy, 4(2), 100114.

Petersen, B., Vanrolleghem, P. A., Gernaey, K., \& Henze, M. (2002). Evaluation of an ASM1 model calibration procedure on a municipal-industrial wastewater treatment plant. Journal of Hydroinformatics, 4(1), 15-38.

Rieger, L., Gillot, S., Langergraber, G., Ohtsuki, T., Shaw, A., Takacs, I., Winkler, S. (2012). Guidelines for using activated sludge models. IWA publishing.

Shahriari, H., Eskicioglu, C., Droste, R. L. (2006). Simulating activated sludge system by simple-toadvanced models. Journal of Environmental Engineering, 132(1), 42-50.

Wu, X., Yang, Y., Wu, G., Mao, J., Zhou, T. (2016). Simulation and optimization of a coking wastewater biological treatment process by activated sludge models (ASM). Journal of Environmental Management, 165, 235-242. 
APPENDIX A. Matrices used for the Sensitivity Analysis

Table S1. ASM1 Real Design Matrix

\begin{tabular}{|c|c|c|c|c|c|c|c|c|c|c|c|c|c|c|c|c|c|c|c|}
\hline & $\mathrm{Yh}$ & Muh & Mua & $\mathrm{Ks}$ & Koh & Koa & Kno & Knh & $\mathrm{Kx}$ & Nug & Nuh & bh & ba & ka & $\mathrm{kh}$ & $\mathrm{Ya}$ & $\mathrm{ixb}$ & $\operatorname{ixp}$ & $\mathrm{fp}$ \\
\hline 1 & 1 & 1 & 1 & 1 & 1 & 1 & 1 & 1 & 1 & 1 & 1 & 1 & 1 & 1 & 1 & 1 & 1 & 1 & 1 \\
\hline 2 & 0.75 & 1 & 1 & 1 & 1 & 1 & 1 & 1 & 1 & 1 & 1 & 1 & 1 & 1 & 1 & 1 & 1 & 1 & 1 \\
\hline 3 & 1.25 & 1 & 1 & 1 & 1 & 1 & 1 & 1 & 1 & 1 & 1 & 1 & 1 & 1 & 1 & 1 & 1 & 1 & 1 \\
\hline 4 & 1 & 0.75 & 1 & 1 & 1 & 1 & 1 & 1 & 1 & 1 & 1 & 1 & 1 & 1 & 1 & 1 & 1 & 1 & 1 \\
\hline 5 & 1 & 1.25 & 1 & 1 & 1 & 1 & 1 & 1 & 1 & 1 & 1 & 1 & 1 & 1 & 1 & 1 & 1 & 1 & 1 \\
\hline 6 & 1 & 1 & 0.75 & 1 & 1 & 1 & 1 & 1 & 1 & 1 & 1 & 1 & 1 & 1 & 1 & 1 & 1 & 1 & 1 \\
\hline 7 & 1 & 1 & 1.25 & 1 & 1 & 1 & 1 & 1 & 1 & 1 & 1 & 1 & 1 & 1 & 1 & 1 & 1 & 1 & 1 \\
\hline 8 & 1 & 1 & 1 & 0.75 & 1 & 1 & 1 & 1 & 1 & 1 & 1 & 1 & 1 & 1 & 1 & 1 & 1 & 1 & 1 \\
\hline 9 & 1 & 1 & 1 & 1.25 & 1 & 1 & 1 & 1 & 1 & 1 & 1 & 1 & 1 & 1 & 1 & 1 & 1 & 1 & 1 \\
\hline 10 & 1 & 1 & 1 & 1 & 0.75 & 1 & 1 & 1 & 1 & 1 & 1 & 1 & 1 & 1 & 1 & 1 & 1 & 1 & 1 \\
\hline 11 & 1 & 1 & 1 & 1 & 1.25 & 1 & 1 & 1 & 1 & 1 & 1 & 1 & 1 & 1 & 1 & 1 & 1 & 1 & 1 \\
\hline 12 & 1 & 1 & 1 & 1 & 1 & 0.75 & 1 & 1 & 1 & 1 & 1 & 1 & 1 & 1 & 1 & 1 & 1 & 1 & 1 \\
\hline 13 & 1 & 1 & 1 & 1 & 1 & 1.25 & 1 & 1 & 1 & 1 & 1 & 1 & 1 & 1 & 1 & 1 & 1 & 1 & 1 \\
\hline 14 & 1 & 1 & 1 & 1 & 1 & 1 & 0.75 & 1 & 1 & 1 & 1 & 1 & 1 & 1 & 1 & 1 & 1 & 1 & 1 \\
\hline 15 & 1 & 1 & 1 & 1 & 1 & 1 & 1.25 & 1 & 1 & 1 & 1 & 1 & 1 & 1 & 1 & 1 & 1 & 1 & 1 \\
\hline 16 & 1 & 1 & 1 & 1 & 1 & 1 & 1 & 0.75 & 1 & 1 & 1 & 1 & 1 & 1 & 1 & 1 & 1 & 1 & 1 \\
\hline 17 & 1 & 1 & 1 & 1 & 1 & 1 & 1 & 1.25 & 1 & 1 & 1 & 1 & 1 & 1 & 1 & 1 & 1 & 1 & 1 \\
\hline 18 & 1 & 1 & 1 & 1 & 1 & 1 & 1 & 1 & 0.75 & 1 & 1 & 1 & 1 & 1 & 1 & 1 & 1 & 1 & 1 \\
\hline 19 & 1 & 1 & 1 & 1 & 1 & 1 & 1 & 1 & 1.25 & 1 & 1 & 1 & 1 & 1 & 1 & 1 & 1 & 1 & 1 \\
\hline 20 & 1 & 1 & 1 & 1 & 1 & 1 & 1 & 1 & 1 & 0.75 & 1 & 1 & 1 & 1 & 1 & 1 & 1 & 1 & 1 \\
\hline 21 & 1 & 1 & 1 & 1 & 1 & 1 & 1 & 1 & 1 & 1.25 & 1 & 1 & 1 & 1 & 1 & 1 & 1 & 1 & 1 \\
\hline 22 & 1 & 1 & 1 & 1 & 1 & 1 & 1 & 1 & 1 & 1 & 0.75 & 1 & 1 & 1 & 1 & 1 & 1 & 1 & 1 \\
\hline 23 & 1 & 1 & 1 & 1 & 1 & 1 & 1 & 1 & 1 & 1 & 1.25 & 1 & 1 & 1 & 1 & 1 & 1 & 1 & 1 \\
\hline 24 & 1 & 1 & 1 & 1 & 1 & 1 & 1 & 1 & 1 & 1 & 1 & 0.75 & 1 & 1 & 1 & 1 & 1 & 1 & 1 \\
\hline 25 & 1 & 1 & 1 & 1 & 1 & 1 & 1 & 1 & 1 & 1 & 1 & 1.25 & 1 & 1 & 1 & 1 & 1 & 1 & 1 \\
\hline 26 & 1 & 1 & 1 & 1 & 1 & 1 & 1 & 1 & 1 & 1 & 1 & 1 & 0.75 & 1 & 1 & 1 & 1 & 1 & 1 \\
\hline 27 & 1 & 1 & 1 & 1 & 1 & 1 & 1 & 1 & 1 & 1 & 1 & 1 & 1.25 & 1 & 1 & 1 & 1 & 1 & 1 \\
\hline 28 & 1 & 1 & 1 & 1 & 1 & 1 & 1 & 1 & 1 & 1 & 1 & 1 & 1 & 0.75 & 1 & 1 & 1 & 1 & 1 \\
\hline 29 & 1 & 1 & 1 & 1 & 1 & 1 & 1 & 1 & 1 & 1 & 1 & 1 & 1 & 1.25 & 1 & 1 & 1 & 1 & 1 \\
\hline 30 & 1 & 1 & 1 & 1 & 1 & 1 & 1 & 1 & 1 & 1 & 1 & 1 & 1 & 1 & 0.75 & 1 & 1 & 1 & 1 \\
\hline 31 & 1 & 1 & 1 & 1 & 1 & 1 & 1 & 1 & 1 & 1 & 1 & 1 & 1 & 1 & 1.25 & 1 & 1 & 1 & 1 \\
\hline 32 & 1 & 1 & 1 & 1 & 1 & 1 & 1 & 1 & 1 & 1 & 1 & 1 & 1 & 1 & 1 & 0.75 & 1 & 1 & 1 \\
\hline 33 & 1 & 1 & 1 & 1 & 1 & 1 & 1 & 1 & 1 & 1 & 1 & 1 & 1 & 1 & 1 & 1.25 & 1 & 1 & 1 \\
\hline 34 & 1 & 1 & 1 & 1 & 1 & 1 & 1 & 1 & 1 & 1 & 1 & 1 & 1 & 1 & 1 & 1 & 0.75 & 1 & 1 \\
\hline 35 & 1 & 1 & 1 & 1 & 1 & 1 & 1 & 1 & 1 & 1 & 1 & 1 & 1 & 1 & 1 & 1 & 1.25 & 1 & 1 \\
\hline 36 & 1 & 1 & 1 & 1 & 1 & 1 & 1 & 1 & 1 & 1 & 1 & 1 & 1 & 1 & 1 & 1 & 1 & 0.75 & 1 \\
\hline 37 & 1 & 1 & 1 & 1 & 1 & 1 & 1 & 1 & 1 & 1 & 1 & 1 & 1 & 1 & 1 & 1 & 1 & 1.25 & 1 \\
\hline 38 & 1 & 1 & 1 & 1 & 1 & 1 & 1 & 1 & 1 & 1 & 1 & 1 & 1 & 1 & 1 & 1 & 1 & 1 & 0.75 \\
\hline 39 & 1 & 1 & 1 & 1 & 1 & 1 & 1 & 1 & 1 & 1 & 1 & 1 & 1 & 1 & 1 & 1 & 1 & 1 & 1.25 \\
\hline
\end{tabular}


Table S2. ASM3 Real Design Matrix

\begin{tabular}{|c|c|c|c|c|c|c|c|c|c|c|c|c|c|c|c|c|c|c|c|c|c|c|}
\hline & $\mathrm{K}_{\mathrm{x}}$ & $\mathrm{kh}$ & $\mathrm{K}_{\mathrm{o} 2}$ & $\mathrm{~K}_{\mathrm{s}}$ & $\mathrm{K}_{\text {nox }}$ & $\mathrm{k}_{\text {sto }}$ & $\mathrm{K}_{\text {sto }}$ & Muh & Nunox & $\mathrm{bh}_{\mathrm{O} 2}$ & $\mathrm{bh}_{\mathrm{Nox}}$ & bsto $_{\mathrm{O} 2}$ & bsto $_{\mathrm{NOX}}$ & Mua & $\mathrm{K}_{\mathrm{nh} 4}$ & $\mathrm{~K}_{\mathrm{alk}}$ & $\mathrm{K}_{\mathrm{Ao} 2}$ & $\mathrm{~K}_{\text {Anh4 }}$ & Kaalk & bAO2 & bANOX & Kanox \\
\hline 1 & 1 & 1 & 1 & 1 & 1 & 1 & 1 & 1 & 1 & 1 & 1 & 1 & 1 & 1 & 1 & 1 & 1 & 1 & 1 & 1 & 1 & 1 \\
\hline 2 & 0.75 & 1 & 1 & 1 & 1 & 1 & 1 & 1 & 1 & 1 & 1 & 1 & 1 & 1 & 1 & 1 & 1 & 1 & 1 & 1 & 1 & 1 \\
\hline 3 & 1.25 & 1 & 1 & 1 & 1 & 1 & 1 & 1 & 1 & 1 & 1 & 1 & 1 & 1 & 1 & 1 & 1 & 1 & 1 & 1 & 1 & 1 \\
\hline 4 & 1 & 0.75 & 1 & 1 & 1 & 1 & 1 & 1 & 1 & 1 & 1 & 1 & 1 & 1 & 1 & 1 & 1 & 1 & 1 & 1 & 1 & 1 \\
\hline 5 & 1 & 1.25 & 1 & 1 & 1 & 1 & 1 & 1 & 1 & 1 & 1 & 1 & 1 & 1 & 1 & 1 & 1 & 1 & 1 & 1 & 1 & 1 \\
\hline 6 & 1 & 1 & 0.75 & 1 & 1 & 1 & 1 & 1 & 1 & 1 & 1 & 1 & 1 & 1 & 1 & 1 & 1 & 1 & 1 & 1 & 1 & 1 \\
\hline 7 & 1 & 1 & 1.25 & 1 & 1 & 1 & 1 & 1 & 1 & 1 & 1 & 1 & 1 & 1 & 1 & 1 & 1 & 1 & 1 & 1 & 1 & 1 \\
\hline 8 & 1 & 1 & 1 & 0.75 & 1 & 1 & 1 & 1 & 1 & 1 & 1 & 1 & 1 & 1 & 1 & 1 & 1 & 1 & 1 & 1 & 1 & 1 \\
\hline$\overline{9}$ & 1 & 1 & 1 & 1.25 & 1 & 1 & 1 & 1 & 1 & 1 & 1 & 1 & 1 & 1 & 1 & 1 & 1 & 1 & 1 & 1 & 1 & 1 \\
\hline 10 & 1 & 1 & 1 & 1 & 0.75 & 1 & 1 & 1 & 1 & 1 & 1 & 1 & 1 & 1 & 1 & 1 & 1 & 1 & 1 & 1 & 1 & 1 \\
\hline 11 & 1 & 1 & 1 & 1 & 1.25 & 1 & 1 & 1 & 1 & 1 & 1 & 1 & 1 & 1 & 1 & 1 & 1 & 1 & 1 & 1 & 1 & 1 \\
\hline 12 & 1 & 1 & 1 & 1 & 1 & 0.75 & 1 & 1 & 1 & 1 & 1 & 1 & 1 & 1 & 1 & 1 & 1 & 1 & 1 & 1 & 1 & 1 \\
\hline 13 & 1 & 1 & 1 & 1 & 1 & 1.25 & 1 & 1 & 1 & 1 & 1 & 1 & 1 & 1 & 1 & 1 & 1 & 1 & 1 & 1 & 1 & 1 \\
\hline 14 & 1 & 1 & 1 & 1 & 1 & 1 & 0.75 & 1 & 1 & 1 & 1 & 1 & 1 & 1 & 1 & 1 & 1 & 1 & 1 & 1 & 1 & 1 \\
\hline 15 & 1 & 1 & 1 & 1 & 1 & 1 & 1.25 & 1 & 1 & 1 & 1 & 1 & 1 & 1 & 1 & 1 & 1 & 1 & 1 & 1 & 1 & 1 \\
\hline 16 & 1 & 1 & 1 & 1 & 1 & 1 & 1 & 0.75 & 1 & 1 & 1 & 1 & 1 & 1 & 1 & 1 & 1 & 1 & 1 & 1 & 1 & 1 \\
\hline 17 & 1 & 1 & 1 & 1 & 1 & 1 & 1 & 1.25 & 1 & 1 & 1 & 1 & 1 & 1 & 1 & 1 & 1 & 1 & 1 & 1 & 1 & 1 \\
\hline 18 & 1 & 1 & 1 & 1 & 1 & 1 & 1 & 1 & 0.75 & 1 & 1 & 1 & 1 & 1 & 1 & 1 & 1 & 1 & 1 & 1 & 1 & 1 \\
\hline 19 & 1 & 1 & 1 & 1 & 1 & 1 & 1 & 1 & 1.25 & 1 & 1 & 1 & 1 & 1 & 1 & 1 & 1 & 1 & 1 & 1 & 1 & 1 \\
\hline 20 & 1 & 1 & 1 & 1 & 1 & 1 & 1 & 1 & 1 & 0.75 & 1 & 1 & 1 & 1 & 1 & 1 & 1 & 1 & 1 & 1 & 1 & 1 \\
\hline 21 & 1 & 1 & 1 & 1 & 1 & 1 & 1 & 1 & 1 & 1.25 & 1 & 1 & 1 & 1 & 1 & 1 & 1 & 1 & 1 & 1 & 1 & 1 \\
\hline 22 & 1 & 1 & 1 & 1 & 1 & 1 & 1 & 1 & 1 & 1 & 0.75 & 1 & 1 & 1 & 1 & 1 & 1 & 1 & 1 & 1 & 1 & 1 \\
\hline 23 & 1 & 1 & 1 & 1 & 1 & 1 & 1 & 1 & 1 & 1 & 1.25 & 1 & 1 & 1 & 1 & 1 & 1 & 1 & 1 & 1 & 1 & 1 \\
\hline 24 & 1 & 1 & 1 & 1 & 1 & 1 & 1 & 1 & 1 & 1 & 1 & 0.75 & 1 & 1 & 1 & 1 & 1 & 1 & 1 & 1 & 1 & 1 \\
\hline 25 & 1 & 1 & 1 & 1 & 1 & 1 & 1 & 1 & 1 & 1 & 1 & 1.25 & 1 & 1 & 1 & 1 & 1 & 1 & 1 & 1 & 1 & 1 \\
\hline 26 & 1 & 1 & 1 & 1 & 1 & 1 & 1 & 1 & 1 & 1 & 1 & 1 & 0.75 & 1 & 1 & 1 & 1 & 1 & 1 & 1 & 1 & 1 \\
\hline 27 & 1 & 1 & 1 & 1 & 1 & 1 & 1 & 1 & 1 & 1 & 1 & 1 & 1.25 & 1 & 1 & 1 & 1 & 1 & 1 & 1 & 1 & 1 \\
\hline 28 & 1 & 1 & 1 & 1 & 1 & 1 & 1 & 1 & 1 & 1 & 1 & 1 & 1 & 0.75 & 1 & 1 & 1 & 1 & 1 & 1 & 1 & 1 \\
\hline 29 & 1 & 1 & 1 & 1 & 1 & 1 & 1 & 1 & 1 & 1 & 1 & 1 & 1 & $\begin{array}{ll}1.25 \\
\end{array}$ & 1 & 1 & 1 & 1 & 1 & 1 & 1 & 1 \\
\hline
\end{tabular}




\section{Table S2 (Continues). ASM3 Real Design Matrix}

\begin{tabular}{|c|c|c|c|c|c|c|c|c|c|c|c|c|c|c|c|c|c|c|c|c|c|c|}
\hline 30 & 1 & 1 & 1 & 1 & 1 & 1 & 1 & 1 & 1 & 1 & 1 & 1 & 1 & 1 & 0.75 & 1 & 1 & 1 & 1 & 1 & 1 & 1 \\
\hline 31 & 1 & 1 & 1 & 1 & 1 & 1 & 1 & 1 & 1 & 1 & 1 & 1 & 1 & 1 & 1.25 & 1 & 1 & 1 & 1 & 1 & 1 & 1 \\
\hline 32 & 1 & 1 & 1 & 1 & 1 & 1 & 1 & 1 & 1 & 1 & 1 & 1 & 1 & 1 & 1 & 0.75 & 1 & 1 & 1 & 1 & 1 & 1 \\
\hline 33 & 1 & 1 & 1 & 1 & 1 & 1 & 1 & 1 & 1 & 1 & 1 & 1 & 1 & 1 & 1 & 1.25 & 1 & 1 & 1 & 1 & 1 & 1 \\
\hline 34 & 1 & 1 & 1 & 1 & 1 & 1 & 1 & 1 & 1 & 1 & 1 & 1 & 1 & 1 & 1 & 1 & 0.75 & 1 & 1 & 1 & 1 & 1 \\
\hline 35 & 1 & 1 & 1 & 1 & 1 & 1 & 1 & 1 & 1 & 1 & 1 & 1 & 1 & 1 & 1 & 1 & 1.25 & 1 & 1 & 1 & 1 & 1 \\
\hline 36 & 1 & 1 & 1 & 1 & 1 & 1 & 1 & 1 & 1 & 1 & 1 & 1 & 1 & 1 & 1 & 1 & 1 & 0.75 & 1 & 1 & 1 & 1 \\
\hline 37 & 1 & 1 & 1 & 1 & 1 & 1 & 1 & 1 & 1 & 1 & 1 & 1 & 1 & 1 & 1 & 1 & 1 & 1.25 & 1 & 1 & 1 & 1 \\
\hline 38 & 1 & 1 & 1 & 1 & 1 & 1 & 1 & 1 & 1 & 1 & 1 & 1 & 1 & 1 & 1 & 1 & 1 & 1 & 0.75 & 1 & 1 & 1 \\
\hline 39 & 1 & 1 & 1 & 1 & 1 & 1 & 1 & 1 & 1 & 1 & 1 & 1 & 1 & 1 & 1 & 1 & 1 & 1 & 1.25 & 1 & 1 & 1 \\
\hline 40 & 1 & 1 & 1 & 1 & 1 & 1 & 1 & 1 & 1 & 1 & 1 & 1 & 1 & 1 & 1 & 1 & 1 & 1 & 1 & 0.75 & 1 & 1 \\
\hline 41 & 1 & 1 & 1 & 1 & 1 & 1 & 1 & 1 & 1 & 1 & 1 & 1 & 1 & 1 & 1 & 1 & 1 & 1 & 1 & 1.25 & 1 & 1 \\
\hline 42 & 1 & 1 & 1 & 1 & 1 & 1 & 1 & 1 & 1 & 1 & 1 & 1 & 1 & 1 & 1 & 1 & 1 & 1 & 1 & 1 & 0.75 & 1 \\
\hline 43 & 1 & 1 & 1 & 1 & 1 & 1 & 1 & 1 & 1 & 1 & 1 & 1 & 1 & 1 & 1 & 1 & 1 & 1 & 1 & 1 & 1.25 & 1 \\
\hline 44 & 1 & 1 & 1 & 1 & 1 & 1 & 1 & 1 & 1 & 1 & 1 & 1 & 1 & 1 & 1 & 1 & 1 & 1 & 1 & 1 & 1 & 0.75 \\
\hline 45 & 1 & 1 & 1 & 1 & 1 & 1 & 1 & 1 & 1 & 1 & 1 & 1 & 1 & 1 & 1 & 1 & 1 & 1 & 1 & 1 & 1 & 1.25 \\
\hline
\end{tabular}

